\title{
Functional Expression of Organic Anion Transporting Polypeptide 1a4 Is Regulated by Transforming Growth Factor- $\beta$ /Activin Receptor-like Kinase 1 Signaling at the Blood-Brain Barrier $\$$
}

\author{
Wazir Abdullahi, Hrvoje Brzica, Nicholas A. Hirsch, Bianca G. Reilly, \\ and Patrick T. Ronaldson \\ Department of Pharmacology, College of Medicine, University of Arizona, Tucson, Arizona \\ Received May 4, 2018; accepted September 26, 2018
}

\section{ABSTRACT}

Central nervous system (CNS) drug delivery can be achieved by targeting drug uptake transporters such as Oatp1a4. In fact, many drugs that can improve neurologic outcomes in CNS diseases [3-hydroxy-3-methylglutaryl-CoA reductase inhibitors (i.e., statins)] are organic anion transporting polypeptide (OATP) transport substrates. To date, transport properties and regulatory mechanisms of Oatp1a4 at the blood-brain barrier (BBB) have not been rigorously studied. Such knowledge is critical to develop Oatp1a4 for optimization of CNS drug delivery and for improved treatment of neurological diseases. Our laboratory has demonstrated that the transforming growth factor- $\beta$ (TGF- $\beta$ )/activin receptor-like kinase 1 (ALK1) signaling agonist bone morphogenetic protein 9 (BMP-9) increases functional expression of Oatp1a4 in rat brain microvessels. Here, we expand on this work and show that BMP-9 treatment increases blood-to-brain transport and brain exposure of established OATP transport substrates (i.e., taurocholate, atorvastatin, and pravastatin). We also demonstrate that BMP-9 activates the TGF- $\beta$ /ALK1 pathway in brain microvessels as indicated by increased nuclear translocation of specific Smad proteins associated with signaling mediated by the ALK1 receptor (i.e., pSmad1/5/8). Furthermore, we report that an activated Smad protein complex comprised of phosphorylated Smad $1 / 5 / 8$ and Smad 4 is formed following BMP-9 treatment and binds to the promoter of the S/co1a4 gene (i.e., the gene that encodes Oatp1a4). This signaling mechanism causes increased expression of S/co1a4 mRNA. Overall, this study provides evidence that Oatp1a4 transport activity at the BBB is directly regulated by TGF- $\beta$ /ALK1 signaling and indicates that this pathway can be targeted for control of CNS delivery of OATP substrate drugs.

\section{Introduction}

To achieve neuroprotection, drugs must accumulate to effective concentrations in the brain. This objective is a considerable challenge due to the blood-brain barrier (BBB), which has evolved to restrict central nervous system (CNS) uptake of xenobiotics (Pardridge, 2012). Tight junction protein complexes form the physical "seal" of the BBB and limit paracellular diffusion. Additionally, efflux transporters such as P-glycoprotein are biochemical BBB features that impair CNS drug delivery (Ronaldson and Davis, 2013; Abdullahi et al., 2017b). Blood-tobrain transport can be achieved via sodium-independent uptake

This work was supported by grants from the National Institutes of Health National Institute of Neurologic Diseases and Stroke [Grant R01-NS084941] and the Arizona Biomedical Research Commission [Grant ADHS16-162406] to P.T.R.

https://doi.org/10.1124/mol.118.112912.

S This article has supplemental material available at molpharm. aspetjournals.org. transporters such as organic anion transporting polypeptides (OATPs). At the human BBB, the principal OATP isoform that is involved in drug transport is OATP1A2 (Hagenbuch and Meier, 2004; Ronaldson and Davis, 2013). Previous studies have confirmed OATP1A2 localization to brain microvascular endothelial cells (Bronger et al., 2005; Lee et al., 2005). Oatp1a4, the rodent ortholog of OATP1A2, is also expressed in microvascular endothelial cells in rat brain (Ronaldson et al., 2011; Thompson et al., 2014; Abdullahi et al., 2017a; Brzica et al., 2017, 2018b). Previous studies in rodents have shown that Oatp1a4 can transport prototypical OATP substrates [taurocholate and 3-hydroxy-3methylglutaryl-CoA reductase inhibitors (i.e., statins)] (Ose et al., 2010; Ronaldson et al., 2011; Thompson et al., 2014; Abdullahi et al., 2017a; Brzica et al., 2018b). Statins are particularly intriguing transport substrates because they possess neuroprotective properties that can improve functional outcomes in CNS diseases (Barone et al., 2012; Montecucco et al., 2012; Sutherland et al., 2012).

ABBREVIATIONS: ALK, activin receptor-like kinase; AUC, area under the curve; BBB, blood-brain barrier; BMP-9, bone morphogenetic protein 9; BSP, bromosulfophthalein; CER, cytoplasmic extraction reagent; ChIP, chromatin immunoprecipitation; Cl, confidence interval; CNS, central nervous system; Co-IP, coimmunoprecipitation; E3S, estrone-3-sulfate; FEX, fexofenadine; JNK, Jun N-terminal kinase; LDN193189, 4-[6-[4-(1piperazinyl)phenyl]pyrazolo[1,5-a]pyrimidin-3-yl]quinoline dihydrochloride; OATP, organic anion transporting polypeptide; PCR, polymerase chain reaction; pERK1/2, phosphorylated extracellular signal-regulated kinase 1/2; SBE, Smad binding element; TGF- $\beta$, transforming growth factor- $\beta$. 
Development of OATPs as molecular CNS drug delivery targets requires characterization of their regulatory mechanisms at the BBB. One such mechanism is transforming growth factor- $\beta$ (TGF- $\beta$ ) signaling, which can modulate Oatp1a4 functional expression in rat brain microvessels (Ronaldson et al., 2011; Thompson et al., 2014; Abdullahi et al., 2017a). TGF- $\beta$ signaling at the BBB is facilitated by transmembrane serine-threonine kinase receptors [i.e., activin receptor-like kinase (ALK)-1 and ALK5]. ALK1 and ALK5 constitute the primary TGF- $\beta$ receptors that mediate vascular remodeling and angiogenesis (Oh et al., 2000) and have been shown to induce opposite effects at the BBB (Lebrin et al., 2005; Ronaldson et al., 2009; Curado et al., 2014; Wei et al., 2014; Li et al., 2016). Effects of TGF- $\beta /$ ALK1 signaling at the $\mathrm{BBB}$ can be studied using the well-characterized ALK1 receptor agonist bone morphogenetic protein 9 (BMP-9) (Brown et al., 2005; Herrera et al., 2014). Upon ligand binding at ALK1, the corresponding type II receptor is recruited to form a heterotetrameric complex. Subsequently, the activated ALK1 receptor intracellularly phosphorylates specific ALK1 receptor Smads (i.e., Smad1/5/8) and proceeds to form a heterotrimeric complex with the common Smad (i.e., Smad4) (Wang et al., 2014). This Smad complex is capable of nuclear translocation and binding to transcription coactivators p300/CBP at the Smad binding element (SBE) composed of the sequence CAGAC (Massagué and Wotton, 2000; Puente et al., 2001; López-Rovira et al., 2002; Suzuki et al., 2010; Morikawa et al., 2013). It has also been reported that these CAGA boxes are flanked with GC-rich regions termed GC-rich Smad1/5 binding element (GC-SBE) (Morikawa et al., 2011, 2013).

We have recently shown that activation of ALK1 signaling with BMP-9 increases Oatp1a4 functional expression at the BBB (Abdullahi et al., 2017a). In this study, BMP-9 effects on Oatp1a4 protein expression and transport activity were attenuated by 4-[6-[4-(1-piperazinyl)phenyl]pyrazolo[1,5a]pyrimidin-3-yl]quinoline dihydrochloride (LDN193189) (Abdullahi et al., 2017a). Since LDN193189 is a pharmacological ALK1 receptor antagonist (Mayeur et al., 2015), our results implicate the TGF- $\beta / \mathrm{ALK} 1$ pathway in mediating this response (Abdullahi et al., 2017a). To date, the ability of BMP9 to directly modulate Oatp1a4 functional expression has not been studied. Here, we address this critical issue by rigorously characterizing the TGF- $\beta$ /ALK1 signaling pathway and its role in controlling expression and activity of Oatp1a4 at the BBB. We show that activation of ALK1 by BMP-9 increases Slco1a4 gene transcript and Oatp1a4 protein expression in rat brain microvessels in a time-dependent manner. This enhancement in transporter expression correlated with increased brain uptake of Oatp1a4 transport substrates. We demonstrate that Oatp1a4 functional expression is directly regulated by $\mathrm{TGF}-\beta / \mathrm{ALK} 1$ signaling as indicated by an increased nuclear-to-cytoplasmic ratio of phosphorylated Smad1/5/8 and increased binding of Smad4-phosphorylatedSmad1/5/8 protein complexes to specific binding sites localized to the Slco1a4 gene promoter. Taken together, our novel data provide evidence that the TGF- $\beta$ /ALK1 pathway is a critical regulator of Oatp1a4 functional expression at the BBB. This work is of paramount importance for CNS drug delivery because it characterizes, in detail, an intracellular signaling pathway that can be targeted to control blood-to-brain transport of Oatp1a4 substrate drugs (i.e., statins).

\section{Materials and Methods}

Animals and Drug Treatments. Animal experiments were approved by the University of Arizona Institutional Animal Care and Use Committee and were designed in accordance with the Guide for the Care and Use of Laboratory Animals (https:/grants.nih.gov/ grants/olaw/guide-for-the-care-and-use-of-laboratory-animals.pdf) as adopted by the National Institutes of Health. Female SpragueDawley rats (200-250 g; 3 months old; Envigo, Denver, CO) were intentionally selected for these studies to enable comparison with our previous work on Oatp1a4 functional expression at the BBB (Ronaldson et al., 2011; Thompson et al., 2014; Abdullahi et al., 2017a). Time-matched rats were randomized into treatment groups and injected with either BMP-9 $[1 \mu \mathrm{g} / \mathrm{kg}(1.0 \mathrm{ml} / \mathrm{kg})$ in $0.9 \%$ saline, i.p.; R\&D Systems, Minneapolis, MN] or vehicle (0.9\% saline, i.p.). Inhibition experiments were performed using the established ALK1 antagonist LDN193189 [10 mg/kg $(1.0 \mathrm{ml} / \mathrm{kg})]$ in $0.9 \%$ saline i.p. (Sigma-Aldrich, St. Louis, MO), which was administered 1 hour prior to injection with BMP-9. Following 2-6 hours of BMP-9 treatment, animals were anesthetized $(100 \mathrm{mg} / \mathrm{kg}$ ketamine and $20 \mathrm{mg} / \mathrm{kg}$ xylazine, i.p.) and prepared for brain microvessel isolation.

Microvessel Isolation. Microvessel isolation was performed using a protocol developed in our laboratory (Abdullahi et al., 2017a; Brzica et al., 2018a,b). All steps were performed on ice at $4^{\circ} \mathrm{C}$ to minimize degradation of mRNA and proteins during tissue processing. Following euthanasia by decapitation, brains were harvested and meninges and choroid plexus were removed. Cerebral hemispheres were homogenized at $3700 \mathrm{~g}$ in $5 \mathrm{ml}$ brain microvessel buffer $(300 \mathrm{mM}$ mannitol, $5 \mathrm{mM}$ EGTA, $12 \mathrm{mM}$ Tris $\mathrm{HCl}, \mathrm{pH}$ 7.4) containing $0.1 \%$ protease inhibitor cocktail (Sigma-Aldrich). At this time, $8 \mathrm{ml} 26 \%$ (w/v) dextran solution (MW 75,000; Spectrum Chemical Manufacturing Corporation, Gardena, CA) was added to each homogenate sample. Samples were then thoroughly vortexed and centrifuged at $5000 \mathrm{~g}$ for 15 minutes at $4^{\circ} \mathrm{C}$. The supernatant was then aspirated and capillary pellets were resuspended in $5 \mathrm{ml}$ of brain microvessel buffer. Dextran homogenization and centrifugation steps were repeated an additional three times to ensure appropriate quality of microvessels as demonstrated in our recent publication (Abdullahi et al., 2017a). Following completion of dextran homogenization and centrifugation, the supernatant was aspirated and the microvessel pellet was resuspended in $5 \mathrm{ml}$ of brain microvessel buffer. At this time, samples consisting of enriched whole microvessels were either processed for RNA extraction or subjected to total membrane isolation. For total membrane isolation, samples were homogenized at $3700 \mathrm{~g}$, placed into ultracentrifuge tubes, and centrifuged at $150,000 \mathrm{~g}$ for 60 minutes at $4^{\circ} \mathrm{C}$. Pellets containing total cellular membranes (Brzica et al., 2009) were resuspended in $500 \mu \mathrm{l}$ of storage buffer (50\% brain microvessel isolation buffer; $50 \% \mathrm{diH}_{2} \mathrm{O}, \mathrm{v} / \mathrm{v}$ ) containing $0.1 \%$ protease inhibitor cocktail. Samples were stored at $-80^{\circ} \mathrm{C}$ until further use, except for samples that were used immediately for RNA extraction. We have previously confirmed the purity of our microvessel preparations by demonstrating enrichment in platelet endothelial cell adhesion molecule-1 compared with expression of astrocyte marker proteins (i.e., glial fibrillary acidic protein) or neuronal marker proteins (i.e., synaptophysin) (Abdullahi et al., 2017a; Brzica et al., 2018a,b).

Nuclear and Cytoplasmic Extraction. Isolated microvessel samples were fractionated using the NE-PER Nuclear and Cytoplasmic Extraction Kit (Thermo Fisher Scientific, Waltham, MA) according to the manufacturer's instructions. Using the volume ratio for cytoplasmic extraction reagent (CER) I and CERII and nuclear extraction reagent of 200:11:100 $\mu$ l, respectively, pelleted capillary microvessel samples were resuspended with CERI containing $0.1 \%$ protease inhibitor cocktail (Sigma-Aldrich) and $5 \mathrm{mM}$ sodium orthovanadate (Sigma-Aldrich), and then incubated on ice for 10 minutes. Ice-cold CERII was then added to each sample, vortexed vigorously, and incubated on ice for 1 minute. Samples were then centrifuged at $16,000 \mathrm{~g}$ for 5 minutes at $4^{\circ} \mathrm{C}$ and the supernatant, which represents the cytoplasmic fraction, was immediately collected and stored at $-80^{\circ} \mathrm{C}$ until required for analysis. The insoluble pellet, which represents the 
nuclear fraction, was resuspended with nuclear extraction reagent containing $0.1 \%$ protease inhibitor cocktail and $5 \mathrm{mM}$ sodium orthovanadate and incubated on ice for 40 minutes while being vortexed vigorously every 10 minutes. Samples were then centrifuged at $16,000 \mathrm{~g}$ for 10 minutes at $4^{\circ} \mathrm{C}$ and the supernatant, which represents the nuclear fraction, was immediately collected and stored at $-80^{\circ} \mathrm{C}$.

Quantitative Real-Time Polymerase Chain Reaction Analysis. All buffers used during microvessel isolation for samples that were processed for total RNA extraction were treated with diethyl pyrocarbonate to limit RNA degradation by RNases during tissue processing. Total RNA was extracted from brain microvessels isolated from control, BMP-9-treated, and LDN193189/BMP-9-treated rats using the Aurum Total RNA Extraction Kit (Bio-Rad, Hercules, CA). The concentration of extracted RNA in each sample was quantified spectrophotometrically by measuring UV absorbance at $260 \mathrm{~nm}$. Extracted RNA $(1.0 \mu \mathrm{g})$ was treated with amplification grade DNaseI (Bio-Rad) to remove contaminating genomic DNA. The iScript Reverse Transcriptase Kit (Bio-Rad) was used to synthesize first-strand cDNA. Primer pairs were prepared by Integrated DNA Technologies (Coralville, IA). Primer sequences for amplification of Slcola4 mRNA were as follows: forward primer $5^{\prime}$-GCTTCTTCATAAAAACAGCAGTAA-3'; reverse primer 5'-TGCACATGTTAATGCCAACAG-3'. Primers were designed to be complementary to sequences located on two different exons separated by an intron to avoid amplification of genomic DNA. Quantitative polymerase chain reaction (PCR) was performed using SYBR Green Master Mix (Bio-Rad) on a CFX96 Touch Real-Time PCR Detection System (Bio-Rad). The quantity of the target gene (i.e., Slco1a4) was normalized to GAPDH using the $\Delta-\Delta$ Cq method. Primer sequences for amplification of GAPDH mRNA were previously published by our laboratory (Ibbotson et al., 2017).

Western Blot Analysis. Western blotting was performed as previously described (Abdullahi et al., 2017a). Isolated microvessel and fractionated samples were quantified for total protein using Bradford reagent (Sigma-Aldrich), and heated at $37^{\circ} \mathrm{C}$ for 30 minutes under reducing conditions [i.e., 2.5\% (v/v) 2-mercaptoethanol (Sigma-Aldrich) in 1X Laemmli sample buffer (Bio-Rad) for Oatp1a4 and phosphorylated extracellular signal-regulated kinase 1/2 (pERK1/2) detection]. For pSmad1/5/8 and phosphorylated Jun N-terminal kinase (JNK) detection, samples were heated at $95^{\circ} \mathrm{C}$ for 5 minutes under reducing conditions [i.e., $2.5 \%(\mathrm{v} / \mathrm{v}) 2$-mercaptoethanol in $1 \mathrm{X}$ Laemmli sample buffer]. Following SDS-PAGE and transfer, polyvinylidene difluoride membranes were incubated overnight at $4^{\circ} \mathrm{C}$ with primary antibodies against Oatp1a4 (anti-Oatp2, sc-33610; $0.2 \mu \mathrm{g} / \mathrm{ml}$ at 1:1000 dilution; Santa Cruz Biotechnology, Dallas, TX), pERK1/2 (anti-pERK1/2, 9101; $1.0 \mathrm{mg} / \mathrm{ml}$ at 1:1000 dilution; Cell Signaling Technology, Danvers, MA), pSmad1/5/8 (anti-pSmad1/5/8, sc-12353; $200 \mu \mathrm{g} / \mathrm{ml}$ at 1:1000 dilution; Santa Cruz Biotechnology), phosphorylated JNK (anti-phosphorylated JNK, ab124956; $1.594 \mathrm{mg} / \mathrm{ml}$ at 1:2000 dilution; Abcam), lamin B (antilamin B, sc-6217, $100 \mu \mathrm{g} / \mathrm{ml}$ at 1:16,000; Santa Cruz Biotechnology), and tubulin (anti- $\alpha$ tubulin, ab7291, $1 \mathrm{mg} / \mathrm{ml}$ at 1:20,000 dilution; Abcam, Cambridge, MA). Membranes were washed and incubated with horseradish peroxidase-conjugated anti-rabbit IgG (1:40,000 dilution; Jackson ImmunoResearch Laboratories, Inc., West Grove, PA), anti-mouse IgG (1:50,000 dilution; Jackson ImmunoResearch Laboratories, Inc.), or anti-goat IgG (1:40,000; Santa Cruz Biotechnology) for 60 minutes at room temperature. Protein bands were visualized using enhanced chemiluminesence (Super Signal West Pico; Thermo Fisher Scientific), where horseradish peroxidase catalyzes the oxidation of luminol to 3-aminophthalate, leading to emission of low-intensity light that was detected via autoradiography film. Bands were quantitated using ImageJ software (Wayne Rasband, Research Services Branch, National Institute of Mental Health, Bethesda, MD), normalized to tubulin or lamin B and reported as relative values.

Coimmunoprecipitation. Fractionated nuclear and cytoplasmic samples were subjected to coimmunoprecipitation (Co-IP) using the Dynabeads Co-Immunoprecipitation Kit and DynaMag-2 Magnet (Life Technologies, Carlsbad, CA) adhering to the manufacturer's instructions. Briefly, primary antibodies (i.e., Smad 4, pSmad1/5/8;
Santa Cruz Biotechnology) were covalently coupled to the Dynabead M-270 epoxy-coated magnetic beads (5 $\mu$ g antibody per $1 \mathrm{mg}$ beads) and allowed to incubate on a roller at room temperature for 36-48 hours. In parallel, Dynabeads were incubated with buffer in the absence of primary antibody (i.e., negative control), while brain microvessel cell lysate derived from control (i.e., saline-treated) animals that were not subjected to immunoprecipitation (i.e., input sample) was used as a positive control. Antibody-coupled beads were subsequently washed with wash buffers and resuspended in storage buffer to attain a final antibody-coupled bead concentration of $10 \mathrm{mg} / \mathrm{ml}$. At this point, $0.5 \mathrm{mg}$ of antibody-coupled beads were transferred to new $1.5 \mathrm{ml}$ microcentrifuge tubes and $0.1 \mathrm{mg}$ of corresponding nuclear and cytoplasmic samples were introduced into the tube to initiate Co-IP. This mixture was incubated on the roller for 45 minutes at $4^{\circ} \mathrm{C}$. The captured protein complex was washed and eluted using the DynaMag-2 Magnet following the manufacturer's instructions. Samples were stored at $-80^{\circ} \mathrm{C}$ at a final sample concentration of $2 \mathrm{mg} / \mathrm{ml}$ until analysis by SDS-PAGE.

Chromatin Immunoprecipitation. Chromatin immunoprecipitation (ChIP) was performed using the Imprint Chromatin Immunoprecipitation Kit (Sigma-Aldrich) according to the manufacturer's instructions. Briefly, microvessels were isolated from control, BMP-9treated, and LDN193189/BMP-9-treated rats and subsequently crosslinked in buffer containing $1 \%$ formaldehyde for 10 minutes at room temperature. Crosslinking was stopped by addition of glycine to a final concentration of $125 \mathrm{mM}$, followed by centrifugation at $180 \mathrm{~g}$ for 5 minutes at room temperature. At this time, the microvessel pellet was resuspended in $50 \mu \mathrm{l}$ of nuclei preparation buffer and incubated on ice for 10 minutes. Following centrifugation at $180 \mathrm{~g}$ for 10 minutes at $4^{\circ} \mathrm{C}$, the nuclear pellet was resuspended in shearing buffer and incubated on ice for 10 minutes. Chromatin was sheared to 200-1000 base pairs by sonication on ice. Sonicated chromatin was diluted 2-fold in lysis buffer and $100 \mu$ l of diluted sample per immunoprecipitation reaction was used. Each sample was added to individual wells of a 96 -well assay plate, where each well contained $1 \mu \mathrm{g}$ of specific mouse monoclonal Smad4 antibody (B-8; Santa Cruz Biotechnology) that has been tested for use in ChIP assays. Assay plates were incubated for 90 minutes at room temperature on an orbital shaker at $75 \mathrm{rpm}$. In parallel, a no-antibody sample was run as a negative control. At this time, $40 \mu \mathrm{l}$ of DNA release buffer was added to each well and samples were incubated in a water bath at $65^{\circ} \mathrm{C}$ for 15 minutes. Following this step, $40 \mu \mathrm{l}$ of reversing solution was added to each well and samples were incubated in a water bath at $65^{\circ} \mathrm{C}$ for 90 minutes. Washes and elutions were performed in accordance with the manufacturer's instructions for the Imprint ChIP assay kit. Eluted and input DNA samples were purified using a spin column to a final volume of $50 \mu \mathrm{l}$. Quantitative real-time PCR was performed using $2 \mu \mathrm{l}$ of template DNA per $25 \mu$ l of PCR amplification scale as described by Hoque et al. (2012). Quantification of Smad4 complex binding to specific Smad1/5/8 binding sites (i.e., CAGAG sites) within the Slco1a4 gene promoter by SYBR green real-time PCR was performed using forward primer 5'-CCCCAAGTCCTTTCTTGGCA-3' and reverse primer 5'-CAGCCTCTTGGGTGCCT-3'. Primers for ChIP assays were prepared by Integrated DNA Technologies.

In Situ Brain Perfusion. In situ brain perfusion was performed as described previously by our laboratory (Ronaldson et al., 2011; Thompson et al., 2014; Abdullahi et al., 2017a; Brzica et al., 2018b). Following treatment with BMP-9 $(1.0 \mu \mathrm{g} / \mathrm{kg})$ or LDN193189 $(10 \mathrm{mg} / \mathrm{kg}) /$ BMP-9 $(1.0 \mu \mathrm{g} / \mathrm{kg})$, animals were anesthetized and heparinized (10,000 U/kg, i.p.). The common carotid arteries were cannulated with silicone tubing connected to a perfusion circuit. Perfusion pressure and flow rate were maintained at $95-105 \mathrm{~mm} \mathrm{Hg}$ and $3.1 \mathrm{ml} / \mathrm{min}$, respectively. Both jugular veins were severed to allow for perfusate drainage. The perfusate was an erythrocyte-free modified mammalian Ringer's solution consisting of $117 \mathrm{mM} \mathrm{NaCl}, 4.7 \mathrm{mM} \mathrm{KCl}, 0.8 \mathrm{mM}$ $\mathrm{MgSO}_{4}, 1.2 \mathrm{mM} \mathrm{KH}_{2} \mathrm{PO}_{4}, 2.5 \mathrm{mM} \mathrm{CaCl}_{2}, 10 \mathrm{mM}$ d-glucose, $3.9 \%$ (w/v) dextran (molecular weight 60,000 ), and $1.0 \mathrm{~g} / \mathrm{l}$ bovine serum albumin (type IV), $\mathrm{pH} 7.4$, warmed to $37^{\circ} \mathrm{C}$ and continuously oxygenated with 
$95 \% \mathrm{O}_{2} / 5 \% \mathrm{CO}_{2}$. Evan's blue dye $(55 \mathrm{mg} / \mathrm{l})$ was added to the perfusate to serve as a visual marker of BBB integrity. Using a slow-drive syringe pump (Harvard Apparatus Inc., Holliston, MA), $\left[{ }^{3} \mathrm{H}\right]$ taurocholic acid $(1 \mu \mathrm{Ci} / \mathrm{ml} ; 10 \mu \mathrm{M}$ total concentration; PerkinElmer, Boston, MA), $\left[{ }^{3} \mathrm{H}\right]$ atorvastatin $(0.5 \mu \mathrm{Ci} / \mathrm{ml} ; 0.013 \mu \mathrm{M}$ total concentration; American Radiolabeled Chemicals, Inc., St. Louis, MO), or $\left[{ }^{3} \mathrm{H}\right]$ pravastatin $(0.2 \mu \mathrm{Ci} / \mathrm{ml} ; 0.013 \mu \mathrm{M}$ total concentration; American Radiolabeled Chemicals, Inc.) was added to the inflowing perfusion solution at a rate of $0.5 \mathrm{ml} / \mathrm{min}$ per cerebral hemisphere, which resulted in a total flow rate of $3.6 \mathrm{ml} / \mathrm{min}$. For inhibition studies, animals were perfused with Ringer's solution containing transport inhibitor [i.e., $100 \mu \mathrm{M}$ estrone-3-sulfate (E3S), $100 \mu \mathrm{M}$ fexofenadine (FEX), or $1.0 \mathrm{mM}$ bromosulfophthalein (BSP)] for 10 minutes prior to perfusion with $\left[{ }^{3} \mathrm{H}\right]$ taurocholic acid, $\left[{ }^{3} \mathrm{H}\right]$ atorvastatin, or $\left[{ }^{3} \mathrm{H}\right]$ pravastatin. We have previously confirmed the stability of OATP transport substrates in both perfusion medium and jugular vein venous outflow and have shown that they remain intact in our in situ perfusion experiments (Ronaldson et al., 2011; Thompson et al., 2014).

Immediately following perfusion for the desired time (i.e., 2.5, 5, 10, or 20 minutes), rats were decapitated and brains were removed. The meninges and choroid plexus were excised and cerebral hemispheres were sectioned. TS2 tissue solubilizer $(1.0 \mathrm{ml}$; Research Products International, Mt. Prospect, IL) was added to the tissue samples, which were allowed to solubilize for 2 days at room temperature. To eliminate chemiluminescence, $100 \mu \mathrm{l}$ of $30 \%$ glacial acetic acid was added, along with $2.0 \mathrm{ml}$ of Optiphase SuperMix liquid scintillation cocktail (PerkinElmer Life and Analytical Sciences, Boston, MA). Radioactivity was measured using a model 1450 Liquid Scintillation and Luminescence Counter (PerkinElmer Life and Analytical Sciences). Results are reported as picomoles of radiolabeled transport substrate (i.e., taurocholate, atorvastatin, or pravastatin) per milligram of brain tissue $(C ; \mathrm{pmol} / \mathrm{mg}$ tissue), which is equal to the total amount of radioisotope in the brain $\left[C_{\text {Brain }} ; \mathrm{dpm} / \mathrm{mg}\right.$ tissue $]$ divided by the amount of radioisotope in the perfusate $\left[C_{\text {Perfusate; }}\right.$ dpm/pmol]:

$$
C=C_{\text {Brain }} / C_{\text {Perfusate }}
$$

The brain vascular volume in rats has been previously shown to range between 6 and $9 \mu \mathrm{l} / \mathrm{g}$ of brain tissue in perfusion studies utilizing a saline-based bicarbonate buffer (Takasato et al., 1984). Since brain tissue was processed immediately after perfusion with radiolabeled substrate, all uptake values required correction for brain vascular volume [i.e., $8.0 \mu \mathrm{l} / \mathrm{g}$ brain tissue as calculated from data reported by Takasato et al. (1984)] from whole-brain uptake data obtained using $\left[{ }^{3} \mathrm{H}\right]$ taurocholic acid.

Multiple-times uptake data were best fit to a nonlinear leastsquares regression model using the following equation, as described previously (Ronaldson et al., 2011):

$$
C=\left(K_{\text {in }} / k_{\text {out }}\right) \times\left(1-e^{-k_{\text {out }} t}\right)
$$

where $C$ is the concentration of drug per gram of brain tissue; $t$ is time (in minutes); $K_{\mathrm{in}}$ is the calculated uptake transfer constant; and $k_{\text {out }}$ is the brain efflux rate coefficient estimated. Here, $K_{\text {in }}$ is determined from the slope of the linear portion of the uptake curve according to the following equation:

$$
C=K_{\text {in }} \cdot t
$$

The estimated brain volume of distribution was calculated using the following equation as described previously (Ronaldson et al., 2011):

$$
V_{\mathrm{Br}}=K_{\text {in }} / k_{\text {out }}
$$

Area under the curve (AUC) analysis was conducted on multiple-times uptake data over the 0-20-minute perfusion interval (i.e., $\mathrm{AUC}_{0-20}$ ) using the trapezoidal method as an indicator of CNS drug exposure. All kinetic parameters and $\mathrm{AUC}_{0-20}$ values were calculated using Prism 7 graphical and statistical software (GraphPad Software, La Jolla, CA).
Statistical Analysis. Quantitative PCR, western blot, and ChIP data are presented as mean \pm S.D. of three independent experiments, where each treatment group consisted of three to four individual animals ( $n=3$ to 4 ). In situ brain perfusion data are reported as mean \pm S.D. of six individual animals per treatment group. These sample sizes were based on the ability to detect a 35\% difference between treatment with $20 \%$ variability. Statistical significance was determined using one-way analysis of variance followed by post hoc Dunnett's multiple comparisons test. A value of $P<0.05$ was accepted as statistically significant.

\section{Results}

\section{Oatp1a4 Expression at the BBB Is Increased Starting} 4 Hours Post BMP-9 Administration. Previously, we showed that treatment with BMP-9 increases Oatp1a4 protein expression at the rat BBB (Abdullahi et al., 2017a); however, this enhancement was studied at a single time point. To assess the temporal relationship between BMP-9 administration and changes in microvascular expression of Oatp1a4, we conducted a time course study. Rats were treated with $1 \mu \mathrm{g} / \mathrm{kg}$, i.p., BMP-9 for 2, 4, and 6 hours and microvessels were isolated and evaluated for Oatp1a4 protein expression. Densitometric western blot analysis showed Oatp1a4 protein expression (normalized to tubulin) in control (i.e., saline-treated) animals of $0.419 \pm 0.129$ [95\% confidence interval (CI): $0.320,0.518$ ] This changed to $0.591 \pm 0.198$ (95\% CI: $0.438,0.743 ; P<0.05)$ at 4 hours following administration of a single dose of BMP-9, an increase of $41 \%$ (Fig. 1; Supplemental Fig. 1). This enhancement in Oatp1a4 protein expression was maintained at the 6 -hour time point $(P<0.01)$ (Fig. 1; Supplemental Fig. 1). Taken together, these data suggest that a single dose of BMP-9 can increase Oatp1a4 protein expression at the BBB at 4-6 hours following its administration.

Increased Oatp1a4 Protein Expression at the BBB Correlates with Enhanced Brain Uptake of $\left[{ }^{\mathbf{3}} \mathbf{H}\right]$ Taurocholate. To determine whether increased Oatp1a4 expression following BMP-9 treatment correlates with enhanced blood-to-brain transport, we measured brain uptake of $\left[{ }^{3} \mathrm{H}\right]$ taurocholate, a well-known and selective OATP substrate (Ronaldson et al., 2011; Thompson et al., 2014; Abdullahi et al., 2017a; Brzica et al., 2018b). In fact, several rodent OATP isoforms are known to be involved in taurocholate transport including Oatp1a1, Oatp1a4, Oatp1a5, Oatp3a1, and Oatp4a1 (Hagenbuch and Meier, 2004). We have reported that brain microvessels isolated from female Sprague-Dawley rats do not express Oatp1a1, Oatp1a5, Oatp3a1, or Oatp4a1 (Ronaldson et al., 2011); however, an additional OATP isoform (i.e., Oatp1c1) was detected. Transport substrates for Oatp1c1 include thyroxine and conjugated sterols (Westholm et al., 2009a,b), which suggests that this OATP isoform is unlikely to be involved in transport of taurocholate at the BBB (Ronaldson et al., 2011; Ronaldson and Davis, 2013). Therefore, uptake of taurocholate at the $\mathrm{BBB}$ is determined by transport activity associated with Oatp1a4. We performed a multiple-time uptake study where animals were perfused with radiolabeled substrate (i.e., $\left[{ }^{3} \mathrm{H}\right]$ taurocholate) at various time points (i.e., $2.5,5,10$, or 20 minutes). The time course of $\left[{ }^{3} \mathrm{H}\right]$ taurocholate brain uptake $(10 \mu \mathrm{M})$ in saline-treated animals showed increasing accumulation over the entire 20-minute duration of the experiment (Fig. 2A). In animals dosed with BMP-9 (i.e., $1 \mu \mathrm{g} / \mathrm{kg}$, i.p.; 6 -hour treatment prior to perfusion), an increase $(P<0.01)$ in $\left[{ }^{3} \mathrm{H}\right]$ taurocholate uptake was observed 
A

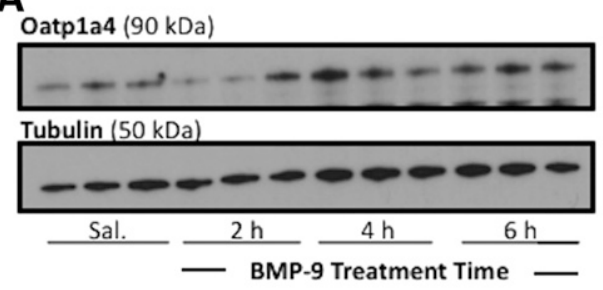

B

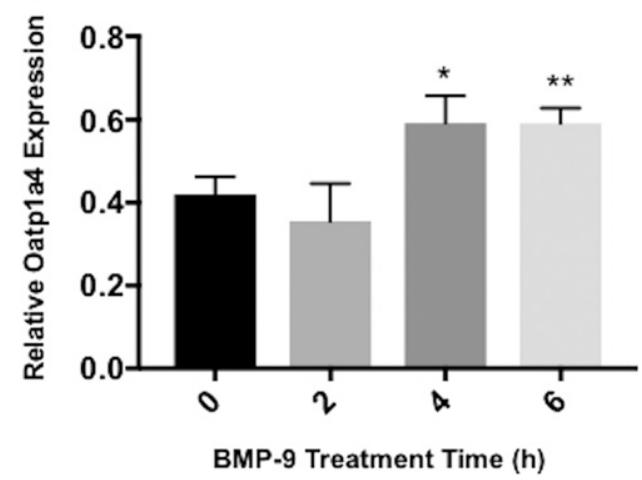

Fig. 1. Activation of ALK1 receptor increases expression of Oatp1a4 at the BBB starting at 4 hours post-BMP-9 treatment. (A) Animals were administered a single dose of BMP-9 $(1 \mu \mathrm{g} / \mathrm{kg}$, i.p.) or $0.9 \%$ saline (indicated as 0 hour). Following the time course of $2-6$ hours, animals were sacrificed and brain microvessels were isolated and prepared for western blot analysis. Isolated microvessels $(10 \mu \mathrm{g})$ were resolved on a $4 \%-12 \%$ SDS-polyacrylamide gel, transferred to polyvinylidene difluoride membrane and analyzed for expression of Oatp1a4. (B) Relative levels of Oatp1a4 protein expression were determined by densitometric analysis and normalized to $\alpha$-tubulin. Drugtreated groups were compared with control groups (i.e., 0 hour group treated with $0.9 \%$ saline only). Western blot data are reported as mean \pm S.D. from at least three independent experiments, where each treatment group consisted of three individual animals $(n=3)$. Asterisks represent data points that were significantly different from control $(* P<0.05$; $* * P<0.01)$.

compared with the uptake time course in saline control (Fig. 2A). These increases were up to $93 \%$ greater than controls at each respective time point. For example, $\left[{ }^{3} \mathrm{H}\right]$ taurocholate uptake at 10 minutes was $65.31 \pm 8.19 \mathrm{pmol} / \mathrm{mg}$ brain tissue in control animals (95\% CI: 49.26, 81.36) and was $125.98 \pm 7.83 \mathrm{pmol} / \mathrm{mg}$ brain tissue in animals treated with BMP-9 (95\% CI: 110.63, 141.33). In contrast, treatment with LDN193189 (10 mg/kg, i.p.) 1 hour prior to dosing with BMP-9 completely attenuated increases in brain $\left[{ }^{3} \mathrm{H}\right]$ taurocholate uptake observed in animals treated with BMP-9 only (Fig. 2A).

Changes in brain exposure to $\left[{ }^{3} \mathrm{H}\right]$ taurocholate that resulted from altered OATP-mediated transport at the $\mathrm{BBB}$ were assessed via $\mathrm{AUC}_{0-20}$ analysis of multiple-times uptake data (Fig. 2B). Following BMP-9 treatment, calculated $\mathrm{AUC}_{0-20}$ values were increased by $79 \%$ [1143.60 $\pm 57.92 \mathrm{pmol} \cdot \mathrm{min} / \mathrm{mg}$ brain tissue for control (95\% CI: 1030.08, 1257.12), $2054.83 \pm$ $66.13 \mathrm{pmol} \cdot \mathrm{min} / \mathrm{mg}$ brain tissue for BMP-9 (95\% CI: 1925.22, 2184.44; $P<0.01$ ] compared with saline controls, which suggests that triggering of the ALK1 receptor leads to a measurable increase in $\left[{ }^{3} \mathrm{H}\right]$ taurocholate brain exposure. In contrast, no statistically significant change in $\mathrm{AUC}_{0-20}$ was observed in animals administered LDN193189 and BMP-9 [1086.11 $\pm 49.92 \mathrm{pmol} \cdot \mathrm{min} / \mathrm{mg}$ brain tissue (95\% CI: 988.27, 1183.95]. Kinetic analysis of multiple-time uptake data showed increases in both $K_{\text {in }}$ and $V_{\mathrm{Br}}$ in BMP-9-treated animals compared with saline controls (Table 1 ). The change in $V_{\mathrm{Br}}$ was particularly critical because this increase following BMP-9 treatment indicates enhanced distribution of taurocholate to the brain. We have previously shown via high-performance liquid chromatography analysis with radiomatic detection that $\left[{ }^{3} \mathrm{H}\right]$ taurocholate remains metabolically intact throughout the procedures used to obtain these data (Ronaldson et al., 2011).

Brain Accumulation of $\left[{ }^{3} \mathbf{H}\right]$ taurocholate Is Mediated by Oatp1a4 at the BBB. To confirm that taurocholate brain uptake is controlled via OATP-mediated transport, we performed in situ brain perfusion studies in salinetreated rats, BMP-9-treated animals, and animals administered LDN193189 and BMP-9 in the presence and absence of OATP inhibitors (i.e., E3S, FEX, or BSP). Statistical analysis of this experiment was conducted using three separate oneway analyses of variance, where control, BMP-9, and LDN193189 + BMP-9 treatments were compared independently. Brain uptake of $\left[{ }^{3} \mathrm{H}\right]$ taurocholate in saline-treated
A

월

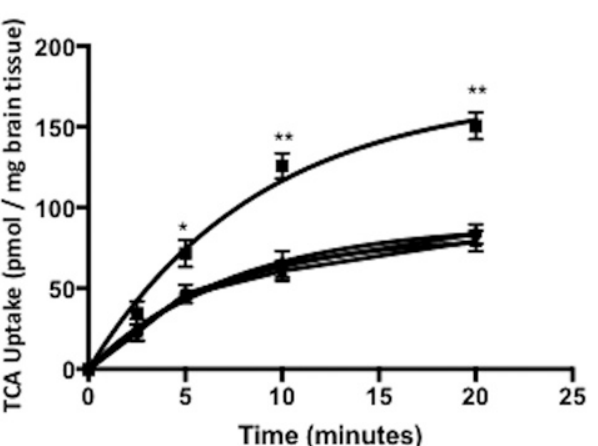

$\rightarrow$ Control

$\rightarrow$ BMP-9 $(1 \mathrm{ug} / \mathrm{kg})$

- $\operatorname{LDN}(10 \mathrm{mg} / \mathrm{kg})+B M P-9(1 \mathrm{ug} / \mathrm{kg})$
$B$

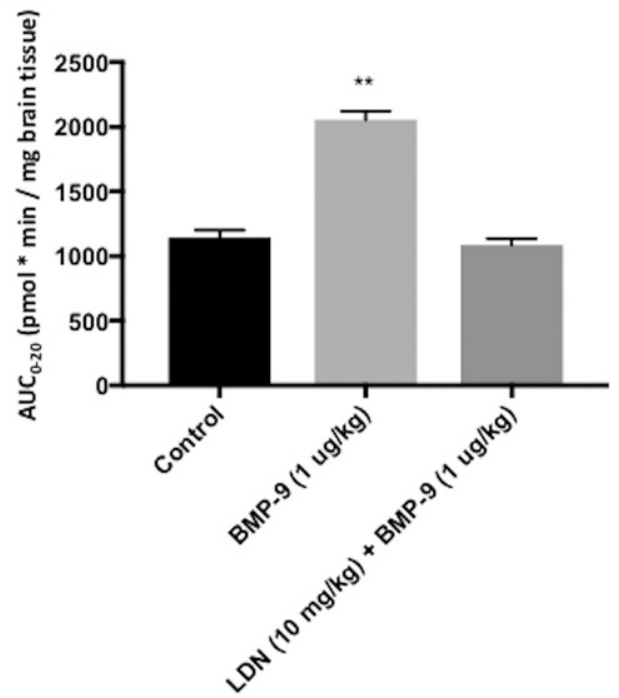

Fig. 2. Brain uptake of $\left[{ }^{3} \mathrm{H}\right]$ taurocholate following 6-hour treatment with BMP-9. (A) Effect of BMP-9 treatment on OATPmediated uptake of $\left[{ }^{3} \mathrm{H}\right]$ taurocholate was measured via a multiple-times uptake in situ brain perfusion study. Animals were treated with BMP-9 $(1 \mu \mathrm{g} / \mathrm{kg}$, i.p.; 6 hours) in the presence and absence of LDN193189 (10 mg/kg, i.p.; 1-hour pretreatment) and perfused with $\left[{ }^{3} \mathrm{H}\right]-$ taurocholic acid $(1.0 \mu \mathrm{Ci} / \mathrm{ml})$ for $2.5,5$, 10 , and 20 minutes. (B) AUC analysis was conducted on multiple-times uptake data using the trapezoidal method to obtain an indicator of CNS total drug exposure. Results are expressed as mean \pm S.D. of six animals per time point. Asterisks represent data points that were significantly different from control (saline-treated) animals $(* P<0.05$; $* * P<0.01)$. 
TABLE 1

Kinetic analysis of multiple-times uptake data of Oatp1a4-mediated $\left[{ }^{3} \mathrm{H}\right]$ taurocholate transport in rat brain

Animals were treated with BMP-9 $(1 \mu \mathrm{g} / \mathrm{kg}$, i.p.) in the presence and absence of LDN193189 (10 mg/kg, i.p.; 1-hour pretreatment) and perfused with $\left[{ }^{3} \mathrm{H}\right]$ taurocholic acid $(1.0 \mu \mathrm{Ci} / \mathrm{ml})$ for $2.5,5,10$, and 20 minutes. Results are expressed as mean \pm S.D. of six animals per treatment group. Asterisks represent data points that were significantly different from control (saline-treated) animals (**P $<0.01$ ).

\begin{tabular}{lccc}
\hline \multicolumn{1}{c}{ Parameter } & Control & BMP-9 & $\begin{array}{c}\text { LDN193189+ } \\
\text { BMP-9 }\end{array}$ \\
\hline$V_{\mathrm{BR}}(\mathrm{pmol} / \mathrm{g})$ & $89.89 \pm 3.69$ & $172.20 \pm 7.19^{* *}$ & $82.85 \pm 3.16$ \\
$K_{\mathrm{IN}}(\mathrm{pmol} / \mathrm{g} \cdot \mathrm{min})$ & $9.37 \pm 1.15$ & $14.34 \pm 1.66^{* *}$ & $9.18 \pm 0.77$ \\
$K_{\text {out }}\left(\mathrm{min}^{-1}\right)$ & $0.104 \pm 0.031$ & $0.083 \pm 0.023$ & $0.111 \pm 0.024$ \\
\hline
\end{tabular}

animals ( $65.31 \pm 8.19 \mathrm{pmol} / \mathrm{mg}$ brain tissue; $95 \%$ CI: 49.26 , 81.36) was reduced by $59 \%$ in the presence of $100 \mu \mathrm{M}$ E3S $(27.02 \pm 7.56 \mathrm{pmol} / \mathrm{mg}$ brain tissue; $95 \%$ CI: 12.20 , $41.84 ; P<0.01)$ and by $61 \%$ via pretreatment with $100 \mu \mathrm{M}$ FEX $(25.61 \pm 7.44 \mathrm{pmol} / \mathrm{mg}$ brain tissue; $95 \%$ CI: 11.02 , $40.20 ; P<0.01$ ) (Fig. 3). No effect on taurocholate uptake was observed in the presence of BSP $(66.81 \pm 7.13 \mathrm{pmol} / \mathrm{mg}$ brain tissue; 95\% CI: 52.84, 80.78), which does not block Oatp1a4mediated transport (Noé et al., 1997; Ronaldson et al., 2011). A similar response was observed in BMP-9-treated animals, where treatment with these same inhibitors resulted in a reduction in brain $\left[{ }^{3} \mathrm{H}\right]$ taurocholate accumulation of up to $69 \%$ [125.98 $\pm 7.83 \mathrm{pmol} / \mathrm{mg}$ brain tissue in control (95\% CI: $110.63,141.33) ; 43.54 \pm 8.55 \mathrm{pmol} / \mathrm{mg}$ brain tissue in animals administered E3S (95\% CI: 26.78, 60.30); $38.78 \pm$ $8.51 \mathrm{pmol} / \mathrm{mg}$ brain tissue in animals administered FEX (95\% CI: $22.08,55.48$ ); and $128.06 \pm 8.00 \mathrm{pmol} / \mathrm{mg}$ brain tissue in animals administered BSP (95\% CI: 112.38, 143.74)] (Fig. 3). $\left[{ }^{3} \mathrm{H}\right]$ Taurocholate accumulation $(60.84 \pm 6.20 \mathrm{pmol} / \mathrm{mg}$

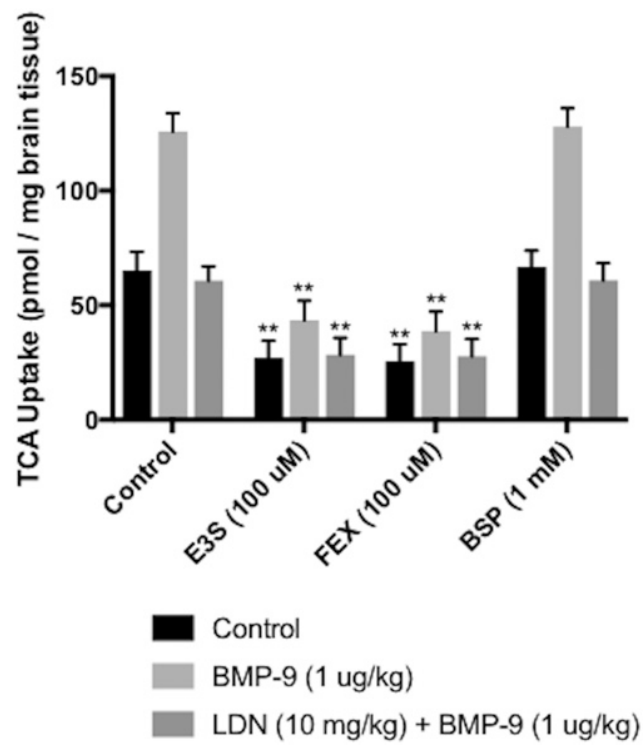

Fig. 3. Brain accumulation of $\left[{ }^{3} \mathrm{H}\right]$ taurocholate is determined by OATPmediated transport at the BBB. Effect of established OATP transport inhibitors (i.e., E3S and FEX) on the uptake of $\left[{ }^{3} \mathrm{H}\right]$ taurocholate into rat brain post-treatment was assessed by in situ brain perfusion studies. $\left[{ }^{3} \mathrm{H}\right]$ taurocholate accumulation was measured in animals injected with BMP-9 (1 $\mu \mathrm{g} / \mathrm{kg}$, i.p.) in the presence and absence of LDN193189 $(10 \mathrm{mg} / \mathrm{kg}$, i.p.; 1 hour pretreatment) where animals were perfused for 10 minutes with E3S $(100 \mu \mathrm{M})$ or $\mathrm{FEX}(100 \mu \mathrm{M})$ or BSP $(1 \mathrm{mM})$ prior to perfusion with $\left[{ }^{3} \mathrm{H}\right]$ taurocholic acid. Results are expressed as mean \pm S.D. of six animals per treatment group. Data points that are significantly different are indicated as follows: $* * P<0.01$. brain tissue; $95 \%$ CI: $48.69,72.99)$ was also decreased $(P<0.01)$ in LDN193189-treated animals in the presence of these same OATP inhibitors [i.e., $28.44 \pm 7.43 \mathrm{pmol} / \mathrm{mg}$ brain tissue; $95 \%$ CI: $13.88,43.00$ (a $53 \%$ reduction by E3S); $27.81 \pm 7.52 \mathrm{pmol} / \mathrm{mg}$ brain tissue; 95\% CI: 13.07, 42.55 (a 54\% decrease by FEX)] (Fig. 3). BSP had no effect on taurocholate brain uptake in rats administered both LDN193189 and BMP-9 (60.90 \pm 7.51 $\mathrm{pmol} / \mathrm{mg}$ brain tissue; $95 \%$ CI: 46.18, 75.62). There were no statistically significant differences in $\left[{ }^{3} \mathrm{H}\right]$ taurocholate uptake between treatments following use of E3S or FEX as a pharmacological OATP transport inhibitor. Taken together, these data confirm that blood-to-brain transport of taurocholate at the BBB is meditated by Oatp1a4.

Brain Accumulation of $\left[{ }^{3} \mathrm{H}\right]$ Atorvastatin and $\left[{ }^{3} \mathrm{H}\right]$ Pravastatin Is Mediated by Oap1a4 at the BBB. To study brain uptake of pharmacologically relevant substrates via OATP-mediated transport, we measured $\left[{ }^{3} \mathrm{H}\right]$ atorvastatin and $\left[{ }^{3} \mathrm{H}\right]$ pravastatin uptake by in situ perfusion. Brain accumulation of equimolar concentrations of these two statins was studied in saline-treated rats, BMP-9-treated animals, and animals administered LDN193189 + BMP-9 in the presence and absence of OATP inhibitors (i.e., E3S). Brain uptake of $\left[{ }^{3} \mathrm{H}\right]$ atorvastatin in saline-treated animals was $34.07 \pm 5.67 \mathrm{pmol} / \mathrm{mg}$ brain tissue (95\% CI: $22.96,45.18)$ following 5-minute perfusion (Fig. 4). CNS accumulation of $\left[{ }^{3} \mathrm{H}\right]$ pravastatin was lower than that of $\left[{ }^{3} \mathrm{H}\right]$ atorvastatin in control animals (22.01 $\pm 6.27 \mathrm{pmol} / \mathrm{mg}$ brain tissue; $95 \%$ CI: 9.91, 34.11; $P<0.01$ ). BMP-9 treatment increased brain uptake of both $\left[{ }^{3} \mathrm{H}\right]$ atorvastatin $(66.41 \pm 6.01 \mathrm{pmol} / \mathrm{mg}$ brain tissue; 95\% CI: $54.63,75.19 ; P<0.01)$ and $\left[{ }^{3} \mathrm{H}\right]$ pravastatin $(60.50 \pm$ $6.05 \mathrm{pmol} / \mathrm{mg}$ brain tissue; $95 \%$ CI: 48.64, 72.36; $P<0.01$ ). Pretreatment with LDN193189 in BMP-9-treated animals

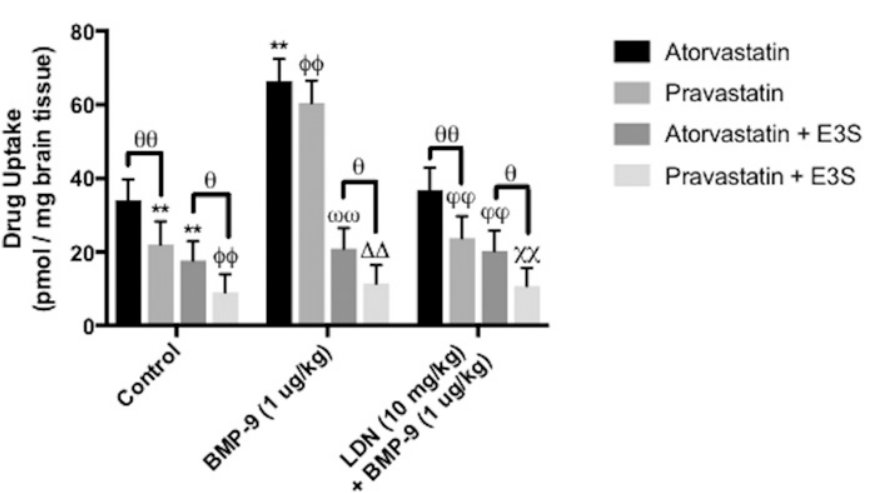

Fig. 4. Brain accumulation of $\left[{ }^{3} \mathrm{H}\right]$ atorvastatin and $\left[{ }^{3} \mathrm{H}\right]$ pravastatin is determined by OATP-mediated transport at the BBB. Effect of an established OATP transport inhibitor (i.e., E3S on the uptake of $\left[{ }^{3} \mathrm{H}\right]$ atorvastatin and $\left[{ }^{3} \mathrm{H}\right]$ pravastatin into rat brain post-treatment was assessed by in situ brain perfusion studies). Accumulation of these drugs was measured in animals injected with BMP-9 $(1 \mu \mathrm{g} / \mathrm{kg}$, i.p.) in the presence and absence of LDN193189 $(10 \mathrm{mg} / \mathrm{kg}$, i.p.; 1-hour pretreatment), where animals were perfused for 5 minutes with E3S $(100 \mu \mathrm{M})$ prior to perfusion with $\left[{ }^{3} \mathrm{H}\right]$ atorvastatin or $\left[{ }^{3} \mathrm{H}\right]$ pravastatin. Results are expressed as mean \pm S.D. of six animals per treatment group. Data points that are significantly different are indicated as follows: $* * P<0.01$, relative to atorvastatin control; $Ф \Phi P<0.01$, relative to pravastatin control; $\omega \omega P<0.01$, relative to atorvastatin uptake in BMP-9treated animals; $\Delta \Delta P<0.01$, relative to pravastatin uptake in BMP-9treated animals; $\phi \phi P<0.01$, relative to atorvastatin uptake in LDN193189 + BMP-9-treated animals; $\chi \chi P<0.01$, relative to pravastatin uptake in LDN193189 + BMP-9-treated animals; and $\theta P<0.05$; $\theta \theta P<0.01$, specific comparisons indicated by black lines. 
attenuated brain uptake of both statin drugs (for $\left[{ }^{3} \mathrm{H}\right]$ atorvastatin, $36.78 \pm 6.11 \mathrm{pmol} / \mathrm{mg}$ brain tissue; $95 \% \mathrm{CI}$ : $24.80,48.76$; for $\left[{ }^{3} \mathrm{H}\right]$ pravastatin, $23.78 \pm 5.95 \mathrm{pmol} / \mathrm{mg}$ brain tissue; $95 \% \mathrm{CI}: 12.12,35.44)$. In the presence of E3S, brain uptake of $\left[{ }^{3} \mathrm{H}\right]$ atorvastatin was reduced in control rats $(17.67 \pm$ $5.22 \mathrm{pmol} / \mathrm{mg}$ brain tissue; $95 \% \mathrm{CI}: 7.44,27.90 ; P<0.01)$, BMP9-treated animals $(20.91 \pm 5.62 \mathrm{pmol} / \mathrm{mg}$ brain tissue; $95 \% \mathrm{CI}$ : 9.89, 31.93; $P<0.01$ ), and animals administered LDN193189 prior to BMP-9 treatment (20.32 $\pm 5.49 \mathrm{pmol} / \mathrm{mg}$ brain tissue; 95\% CI: 9.56, 31.08; $P<0.01$ ). Similarly, E3S blocked CNS accumulation of pravastatin in control animals $(9.00 \pm 4.98$ $\mathrm{pmol} / \mathrm{mg}$ brain tissue; $95 \% \mathrm{CI}:-0.76,18.76 ; P<0.01)$, BMP-9-treated rats $(11.45 \pm 5.00 \mathrm{pmol} / \mathrm{mg}$ brain tissue; $95 \%$ CI: $1.65,21.25 ; P<0.01$ ), and rats pretreated with LDN193189 prior to BMP-9 treatment (10.78 $\pm 4.89 \mathrm{pmol} / \mathrm{mg}$ brain tissue; 95\% CI: $1.20,20.36 ; P<0.01)$. Taken together, these data provide evidence in support of OATP-mediated transport of atorvastatin and pravastatin at the $\mathrm{BBB}$.

BMP-9 Treatment Increases pSmad1/5/8 Expression in Nuclear Extracts Derived from Rat Brain Microvessels. Since our previous studies had shown increased Oatp1a4 functional expression at the BBB following treatment with the ALK1 agonist BMP-9, we needed to design detailed molecular experiments to study signaling mediated by the TGF- $\beta$ /ALK1 pathway. The goal of this work was to show that TGF- $\beta$ /ALK1 signaling can directly target the Slco1a4 gene and induce its transcription. Activation of the ALK1 receptor transduces intracellular signaling by triggering phosphorylation of specific receptor-regulated Smad proteins (i.e., Smad1/5/8) (Abdullahi et al., 2017b). Following phosphorylation, pSmad1/5/8 forms a complex with the common Smad protein (i.e., Smad4), which leads to nuclear translocation and subsequent transcriptional activation of target genes. To study this mechanism of intracellular signaling, brain microvessels were isolated from animals treated with BMP-9 or vehicle and were subjected to cytoplasmic and nuclear extraction. Each fraction was analyzed for protein expression of $\mathrm{pSmad} 1 / 5 / 8$ via western blot (Fig. 5A; Supplemental Fig. 2, A-D). Densitometric data from these western blots enabled us to calculate the nuclear-tocytoplasmic expression ratio, an indicator of activation of the TGF- $\beta$ /ALK1 pathway. That is, a nuclear-to-cytoplasmic ratio of less than 1 indicates a greater degree of pSmad1/5/8 expression in the cytoplasm and a lack of pathway activation. In contrast, a nuclear-to-cytoplasmic ratio that is greater than 1 suggests increased pSmad1/5/8 protein expression in the nucleus, an indicator that the TGF- $\beta / A L K 1$ pathway has been activated in response to a specific treatment. Our data
A
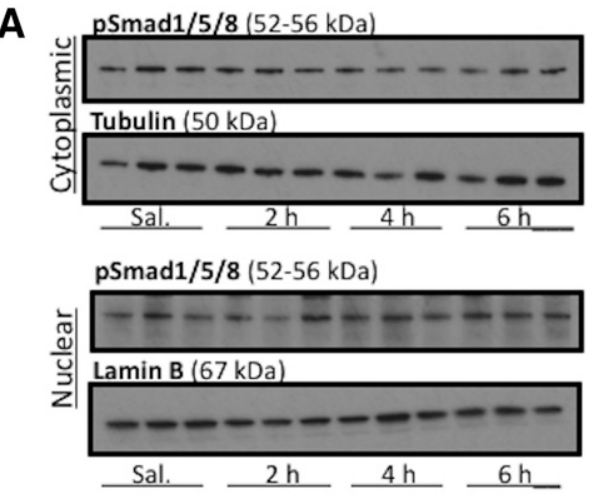

B

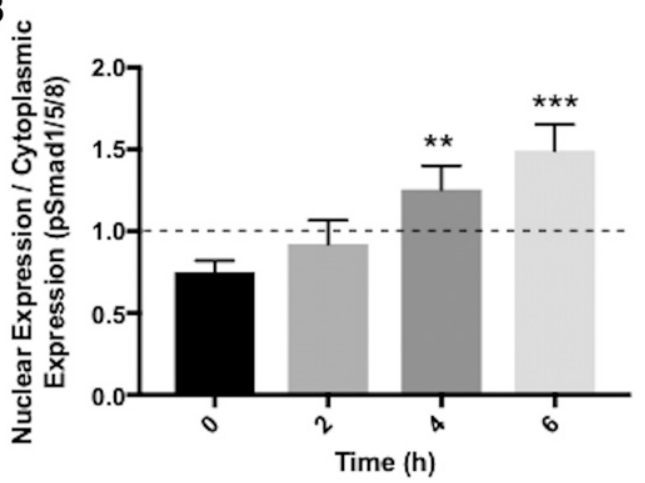

C

Lamin B (67 kDa)

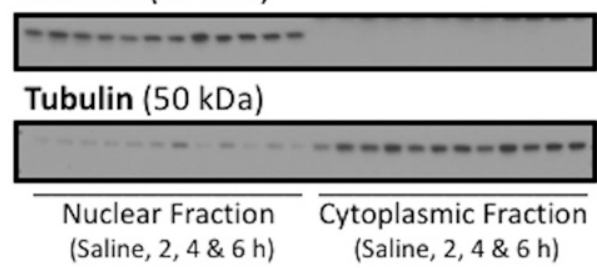

Fig. 5. BMP-9 treatment increases expression of nuclear pSmad1/5/8 in rat brain microvessels. (A) Animals were administered a single dose of BMP-9 $(1 \mu \mathrm{g} / \mathrm{kg}$, i.p. $)$ or $0.9 \%$ saline and treated for 2-6 hours. Animals were sacrificed and brain microvessels were isolated and subjected to nuclear and cytoplasmic fractionation, which was then prepared for western blot analysis. Fractionated samples (10 $\mu \mathrm{g})$ were resolved on a $4 \%-12 \%$ SDS-polyacrylamide gel, transferred to polyvinylidene difluoride membrane and analyzed for expression of pSmad1/5/8. (B) Relative levels of pSmad1/5/8 expression were determined by densitometric analysis and normalized to $\alpha$-tubulin for cytoplasmic fraction and lamin B for nuclear fraction as loading controls. Nuclear-to-cytoplasmic ratio was then determined. (C) Quality of fractionated samples derived from rat brain microvessels was assessed. Western blot analysis was performed where the cytoplasmic fraction was analyzed for expression of lamin B, a nuclear marker protein. Similarly, the nuclear fraction was examined for expression of tubulin, a cytoplasmic marker protein. Drug-treated groups were compared with control groups, i.e., $0.9 \%$ saline-injected animals. Western blot data are reported as mean \pm S.D. from at least three independent experiments, where each treatment group consisted of three individual animals $(n=3)$. Asterisks represent data points that were significantly different from control (saline-treated) animals $(* * P<0.01 ; * * * P<0.001)$ 
show that the nuclear-to-cytoplasmic ratio for pSmad1/5/8 was increased $(P<0.01)$ following 4 -hour BMP-9 treatment and increased $(P<0.001)$ following 6 -hour BMP-9 treatment (Fig. 5B; Supplemental Fig. 2E).

In these studies, it is essential to demonstrate the integrity of these nuclear extracts and cytoplasmic samples derived from our fractionation method. Specifically, rigorous interpretation of these data requires detection of specific biomarkers associated with the nucleus and the cytoplasm to show that minimal crosscontamination occurs during the extraction process (i.e., the cytoplasmic fraction should contain negligible nuclear material and vice versa). Therefore, we performed western blot analysis, where the cytoplasmic fraction was analyzed for expression of lamin B, a nuclear marker protein. Similarly, the nuclear fraction was examined for expression of tubulin, a cytoplasmic marker protein. We were not able to detect lamin B in the cytoplasmic fraction and observed minimal tubulin expression in the nuclear fraction (Fig. 5C). Taken together, these results indicate that our isolation and subsequent fractionation process yielded nuclear and cytoplasmic samples of sufficient purity for our studies on nuclear translocation of $\mathrm{pSmad} 1 / 5 / 8$.

Nuclear translocation of $\mathrm{pSmad} 1 / 5 / 8$ requires proteinprotein interactions with Smad4. Therefore, we performed Co-IP experiments on nuclear and cytoplasmic fractions to demonstrate that treatment with exogenous BMP-9 promotes nuclear expression of protein complexes containing both $\mathrm{pSmad} 1 / 5 / 8$ and Smad4. Our studies showed expression of

\section{A}

Cytoplasmic Fraction - IP: Smad4; IB: pSmad1/5/8

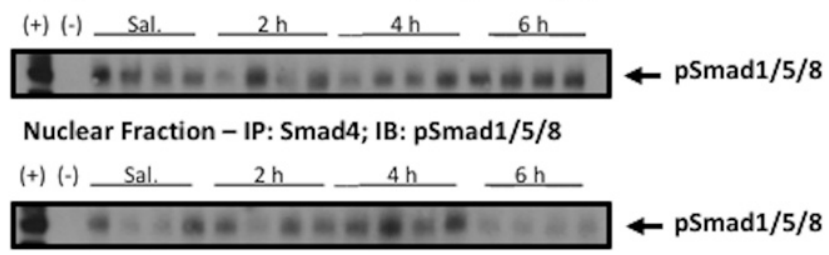

B

Cytoplasmic Fraction - IP: pSmad1/5/8; IB: Smad4

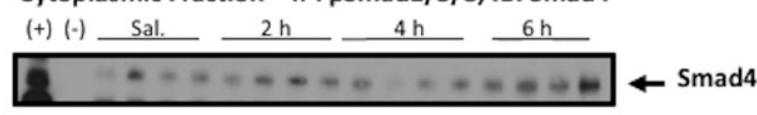

Nuclear Fraction - IP: pSmad1/5/8; IB: Smad4

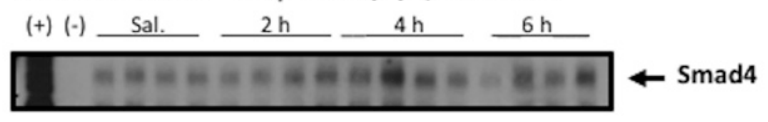

Fig. 6. pSmad1/5/8 complexes with Smad 4 following BMP-9 treatment. (A) BMP-9 dosed ( $1 \mu \mathrm{g} / \mathrm{kg}$, i.p.; 2-6 hours) or $0.9 \%$ saline-treated animals were sacrificed and brain microvessels were isolated and subjected to nuclear and cytoplasmic fractionation followed by Co-IP. Fractionated nuclear and cytoplasmic samples were immunoprecipitated using Smad4 antibody and immunoblotted using pSmad1/5/8 antibody. Each treatment group consisted of four individual animals $(n=4)$ and western blotting was performed in at least three independent experiments. (B) Fractionated nuclear and cytoplasmic samples were immunoprecipitated using pSmad1/5/8 antibody and immunoblotted using Smad4 antibody. Each treatment group consisted of four individual animals $(n=4)$ and western blotting was performed in at least three independent experiments; (+) indicates positive control (i.e., brain microvessel cell lysate derived from saline-treated control animals not subjected to immunoprecipitation); (-) indicates negative control (i.e., Dynabeads incubated with buffer in the absence of primary antibody).
pSmad1/5/8 within protein complexes containing Smad4 at all time points (Fig. 6A). In this experiment, we immunoprecipitated these protein complexes with a specific antibody against Smad 4 and measured pSmad1/5/8 expression by western blot analysis. We performed a similar experiment, where protein complexes were immunoprecipitated using a specific antibody directed against pSmad1/5/8 and Smad4 expression was assessed by western blot analysis. Here, we observed expression of Smad4 in protein complexes containing pSmad1/5/8 following exogenous BMP-9 treatment, suggesting activation of TGF- $\beta$ /ALK1 signaling in rat brain microvessels (Fig. 6B). Control experiments, where both Co-IP and western blotting were performed with the same pSmad1/5/8 antibody and the same Smad4 antibody, showed expression of the immunoprecipitated protein in all samples (data not shown). Overall, our Co-IP studies provide evidence for activation of TGF- $\beta$ /ALK1 signaling at the BBB following administration of an established ALK1 receptor agonist.

BMP-9 Treatment Increases Expression of Slco1a4 mRNA Transcript in Rat Brain Microvessels. To evaluate and quantitate mRNA expression of Slco1a4 mRNA transcripts at the $\mathrm{BBB}$, we performed quantitative PCR and subsequent $\Delta-\Delta \mathrm{Cq}$ analysis. For these experiments, rats were treated with saline, BMP-9 alone, and BMP-9 in the presence of LDN193189. We observed an 83\% increase (relative Slco1a4 expression was $1.83 \pm 0.39$ in BMP-9-treated animals relative to control; $P<0.01$ ) in expression of Slco1a $4 \mathrm{mRNA}$ in rat brain microvessels following 6-hour BMP-9 treatment compared with saline-treated animals (Fig. 7). Pretreatment with the ALK1 inhibitor (LDN193189) for 1 hour prior to BMP-9 administration attenuated the enhancement in Slco1a4 mRNA observed following treatment with BMP-9 only (Fig. 7).

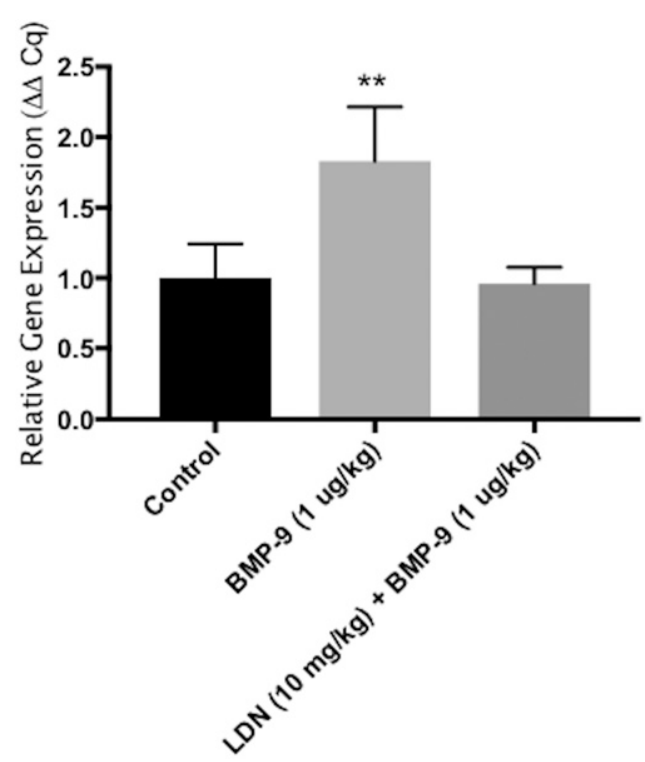

Fig. 7. BMP-9 treatment increases expression of Slco1a4 mRNA transcript in rat brain microvessels. Animals were treated with $0.9 \%$ saline, BMP-9 alone (1 $\mu \mathrm{g} / \mathrm{kg}$, i.p.; 6 hours $)$ or BMP-9 in the presence of LDN193189 (10 mg/kg, i.p.; 1-hour pretreatment) and expression of Slco1a4 mRNA in rat brain microvessels was evaluated. Results are expressed as mean \pm S.D. of three experiments, with each treatment group consisting of three individual animals. Asterisks represent data points that were significantly different from control (saline-treated) animals $(* * P<0.01)$. 
These studies demonstrate that treatment with BMP-9, and subsequent activation of TGF- $\beta$ /ALK1 signaling, can increase expression of Slcola4 at the BBB.

TGF- $\beta$ /ALK1 Signaling Is Involved in Regulation of Slco1a4 mRNA Transcripts in Rat Brain Microvessels Following BMP-9 Treatment. Since our data demonstrated increased pSmad1/5/8 nuclear translocation and enhanced expression of Slco1a4 mRNA expression following BMP-9 treatment, we hypothesized that this pathway may be directly involved in transcriptional regulation of the Slco1a4 gene. To test this hypothesis, we used ChIP to study recruitment of protein complexes containing Smad4 to promoter regions on the Slco1a4 gene that contains the putative pSmad1/5/8 binding site. These binding sites are demarcated by CAGA boxes flanked by GC-rich regions (Morikawa et al., 2011). Our results show that BMP-9 treatment increased $(P<0.01)$ Smad4 complex binding at pSmad1/5/8 binding sites contained within the Slcola 4 promoter, as indicated by a $125 \%$ increase (relative Slco1a4 enrichment was $2.25 \pm 0.46$ in BMP-9treated animals relative to control) in Slco1a4 enrichment (Fig. 8). The observed increase in Slco1a4 enrichment was completely attenuated in animals pretreated with LDN193189 1 hour prior to BMP-9 administration (Fig. 8). These data show that the pSmad1/5/8-Smad4 complex can bind to the promoter of the Slco1a4 gene in brain microvessels following BMP-9 treatment, thereby providing evidence for molecular regulation of a solute carrier transporter family (i.e., Oatp1a4) at the BBB by TGF- $\beta$ /ALK1 signaling.

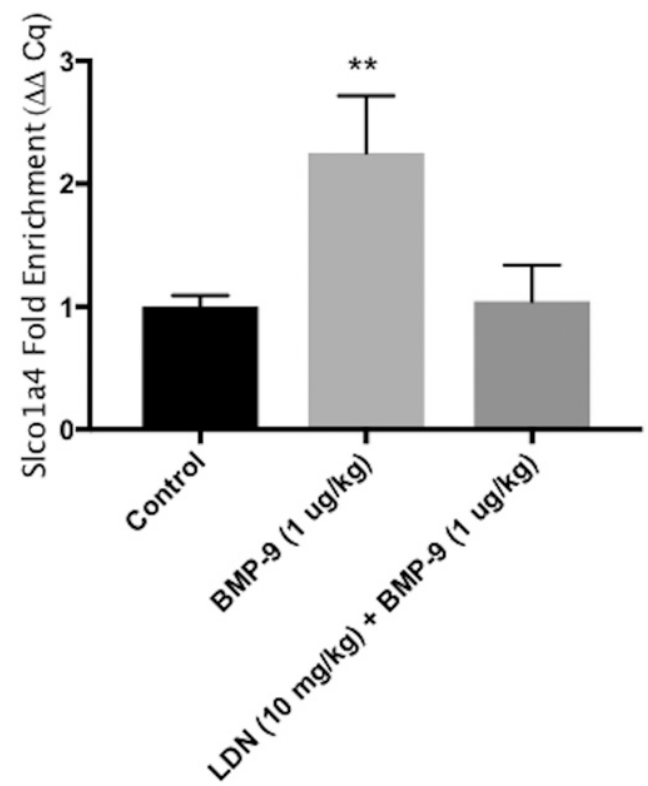

Fig. 8. TGF- $\beta$ /ALK1 signaling is involved in regulation of Slco1a4 mRNA transcripts in rat brain microvessels following BMP-9 treatment. ChIP was performed on brain microvessels isolated from animals treated with $0.9 \%$ saline, BMP-9 alone ( $1 \mu \mathrm{g} / \mathrm{kg}$, i.p.; 6 hours) or BMP-9 in the presence of LDN193189 (10 mg/kg, i.p.; 1-hour pretreatment). Sheared chromatin was immunoprecipitated using Smad4 antibody, and quantification of Smad4 complex binding to specific Smad1/5/8 binding sites within the Slco1a4 gene promoter was performed by real-time PCR. Results are expressed as mean \pm S.D. of three experiments, with each group consisting of microvessels from three individual animals. Asterisks represent data points that were significantly different from control (saline-treated) animals $(* * P<0.01)$.
BMP-9 Treatment Does Not Activate Non-Smad Signaling Pathways. To demonstrate specificity of the bone morphogenetic protein-mediated response that achieved a statistically significant increase in Oatp1a4 expression in rat $\mathrm{BBB}$ via triggering TGF- $\beta / \mathrm{ALK} 1$ signaling, other serinethreonine selective kinases from non-Smad signaling pathways such as extracellular signal-regulated kinase 1/2 (Fig. 9A; Supplemental Fig. 3, A-C) and JNK (Fig. 9C; Supplemental Fig. 3, E-G) were assessed. Western blot analysis showed no change in the nuclear-to-cytoplasmic ratio for either $\mathrm{pERK} 1 / 2$ (Fig. 9B; Supplemental Fig. 3D) or phosphorylated JNK (Fig. 9D; Supplemental Fig. 3H) in BMP-9-treated rats compared with saline-treated control animals. Taken together, these data provide further evidence that BMP-9 selectively targets TGF- $\beta$ /ALK1 signaling at the BBB, an effect that leads to increased functional expression of the drug uptake transporter Oatp1a4.

\section{Discussion}

The BBB is a formidable obstacle to CNS drug delivery that often renders treatment of brain diseases ineffective (Qosa et al., 2016). One such example is ischemic stroke, which is characterized by reduced oxygen and glucose supply to ischemic brain tissue (Liu et al., 2010; Brzica et al., 2017). Treatment of the ischemic core is impossible due to rapid development of necrosis (i.e., within minutes). In contrast, brain tissue that surrounds the core (i.e., the penumbra) is a therapeutic target due to slower cell degradation (Arai et al., 2011). Recent studies have shown that re-establishment of perfusion poststroke may exacerbate neuronal damage and lead to ischemic core enlargement or development of edema (Pan et al., 2007; Nour et al., 2013). These points emphasize the need to advance neuroprotective therapies in ischemic stroke patients; however, many neuroprotectants have failed in clinical trials, in part due to poor $\mathrm{BBB}$ penetration $\mathrm{Xu}$ and Pan, 2013). Interestingly, retrospective clinical studies have revealed that patients who were treated with statins both prior to onset of ischemic stroke or at the time of stroke onset have better outcomes (Ni Chroinin et al., 2013; Carone et al., 2015). While the benefits of statin therapy are generally accepted, the mechanisms used by these compounds to permeate the $\mathrm{BBB}$ are unclear. Indeed, a thorough understanding of $\mathrm{BBB}$ transport mechanisms will allow for development of novel strategies for ischemic stroke treatment.

Considerable research has been conducted in investigating BBB transporters that restrict CNS drug delivery (i.e., ATPbinding cassette efflux transporters such as P-glycoprotein) (Löscher and Potschka, 2002; Palmeira et al., 2012; Abdullahi et al., 2017b). Clinical trials designed to target P-glycoprotein have been unsuccessful due to inhibitor toxicity or enhanced tissue penetration of xenobiotics (Potschka, 2010; Palmeira et al., 2012). Our laboratory has proposed an alternative strategy for CNS drug delivery via targeting of endogenous BBB uptake transporters such as OATP1A2/Oatp1a4. We have shown that atorvastatin exhibits neuroprotective properties using an in vivo model of cerebral hypoxia and reoxygenation stress (i.e., a "component" of ischemic stroke) (Thompson et al., 2014). Specifically, we reported reduced expression of a biomarker for neuronal apoptosis [i.e., poly (ADP-ribose) polymerase cleavage] in rats treated with a single dose (20 mg/kg) of atorvastatin (Thompson et al., 2014). 
A

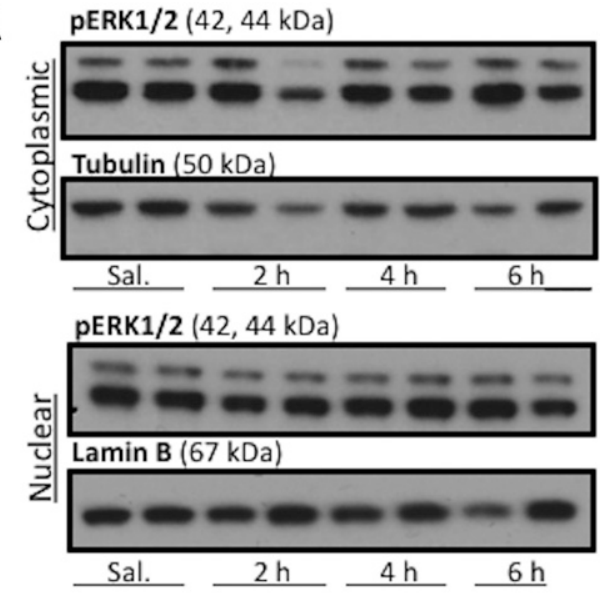

B

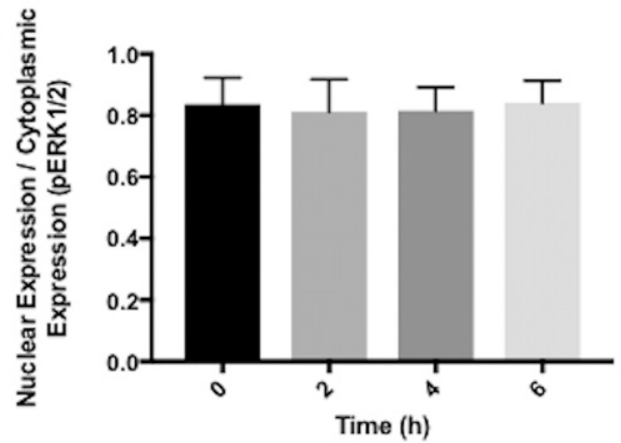

C
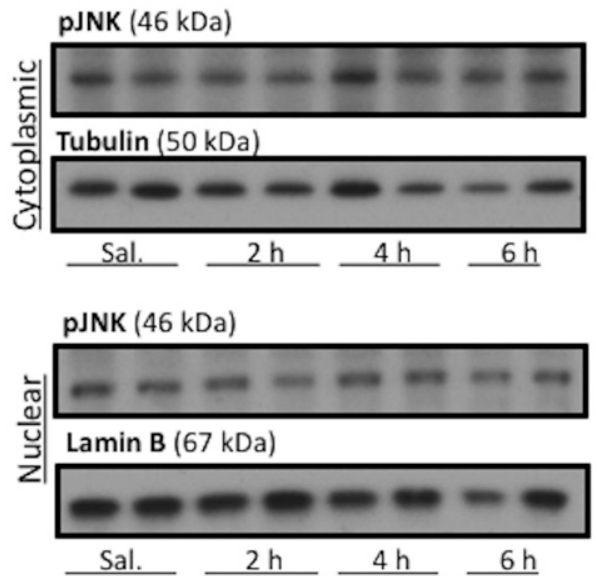

D

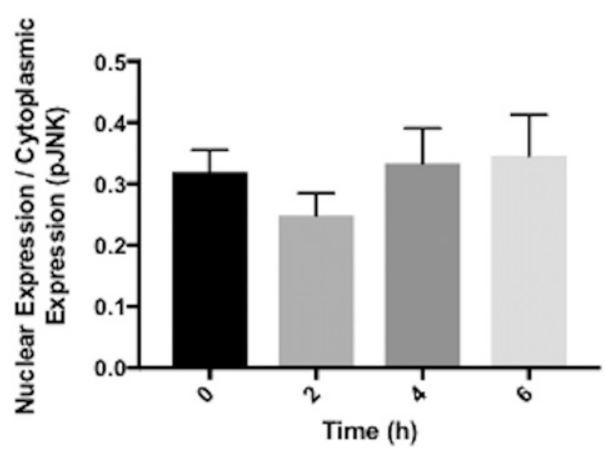

Fig. 9. BMP-9 treatment does not activate mitogen-activated protein kinase signaling pathways. (A) Animals were administered a single dose of BMP-9 $(1 \mu \mathrm{g} / \mathrm{kg}$, i.p. $)$ or $0.9 \%$ saline and treated for $2-6$ hours. Following treatments, animals were sacrificed and brain microvessels were isolated and subjected to nuclear and cytoplasmic fractionation. Nuclear and cytoplasmic extracts were then prepared for western blot analysis. Fractionated microvessels $(10 \mu \mathrm{g})$ were resolved on a $4 \%-12 \%$ SDS-polyacrylamide gel, transferred to polyvinylidene difluoride (PVDF) membrane and analyzed for expression of pERK1/2. (B) Relative levels of pERK1/2 expression in samples from A were determined by densitometric analysis and normalized to $\alpha$-tubulin for cytoplasmic fraction and lamin B for nuclear fraction. (C) Fractionated microvessels (10 $\mu \mathrm{g})$ were resolved on a $4 \%-12 \%$ SDS-polyacrylamide gel, transferred to PVDF membrane and analyzed for expression of phosphorylated JNK (pJNK). (D) Relative levels of pJNK expression in samples from (C) were determined by densitometric analysis and normalized to $\alpha$-tubulin for cytoplasmic fraction and lamin B for nuclear fraction. Western blot data are reported as mean \pm S.D. from at least three independent experiments, where each treatment group consisted of four individual animals $(n=4)$.

We demonstrated that the ability of atorvastatin to provide neuroprotection is dependent upon effective blood-to-brain transport mediated by Oatp1a4 (Thompson et al., 2014). Of particular significance, TGF- $\beta$ signaling mediated by the ALK5 receptor was shown to be involved in regulation of Oatp1a4 expression and activity (Thompson et al., 2014); however, it was not known whether Oatp1a4 functional expression could be controlled by targeting ALK1. Since ALK5 and ALK1 have opposing effects on the microvasculature, we hypothesized that activation of ALK1 with a specific agonist will result in increased Oatp1a4 functional expression at the rat BBB. Our recent publication (Abdullahi et al., 2017a) provided initial evidence in support of this hypothesis. The present study is the logical continuation of this work because we have now rigorously characterized the intracellular signaling mechanism downstream from the ALK1 receptor and its role in modulating Oatp1a4 functional expression at the BBB.

BMP-9 is an endogenous cytokine that is produced by the liver to yield a physiologic concentration range of $2-12 \mathrm{ng} / \mathrm{ml}$ in plasma (Miller et al., 2000; David et al., 2008). It is a potent activator of Smad1/5/8 phosphorylation with an $\mathrm{EC}_{50}$ of $50 \mathrm{pg} / \mathrm{ml}$ for the ALK1 receptor (David et al., 2008). Therefore, we chose to administer a pharmacological dose of BMP-9 (i.e., $1 \mu \mathrm{g} / \mathrm{kg}$ ) that can induce Oatp1a4 protein expression in rat microvessels in vivo (Abdullahi et al., 2017a). In the present study, time course experiments showed that an increase in BBB Oatp1a4 expression can be achieved as early as 4 hours post-treatment. Since we also observed an increase in Slco1a4 gene transcript, the elevation in Oatp1a4 expression following exogenous BMP-9 treatment is likely due to de novo protein synthesis. In fact, this time course of increased Oatp1a4 protein expression (i.e., 4-6 hours) is consistent with the temporal relationship between activation of intracellular signaling and de novo synthesis of other endogenous BBB transporters (Miller and Cannon, 2014). Pretreatment (1 hour) with LDN193189 prior to BMP-9 administration reduced Oatp1a4 protein expression in isolated microvessels (Abdullahi et al., 2017a) and greatly reduced brain accumulation of taurocholate, observations that point toward ALK1 signaling as a critical regulator of Oatp1a4 functional expression. Of translational significance, our study also showed enhanced brain delivery of atorvastatin and pravastatin following BMP-9 treatment. Interestingly, BMP-9 enhancement of Oatp1a4 protein expression and OATP-mediated transport had a greater effect on pravastatin uptake compared with atorvastatin accumulation (i.e., $175 \%$ increase for pravastatin vs. $95 \%$ increase for atorvastatin). These differences in brain uptake were also uncovered when OATP-mediated transport was blocked by E3S, thereby causing brain uptake to be more dependent 
upon transcellular diffusion. Indeed, pravastatin is more hydrophilic than atorvastatin, which suggests that pravastatin is more dependent on OATP-mediated transport to access a target tissue such as the brain. These data are in agreement with a previous study by Higgins et al. (2014), who showed that genetic knockout of OATP isoforms in male FVB mice resulted in a greater magnitude of effect on pravastatin pharmacokinetics compared with atorvastatin. The knowledge that statin uptake into the CNS is mediated via an OATP-dependent transport mechanism indicates that the TGF- $\beta$ /ALK1 pathway can be targeted for development of novel strategies to treat CNS diseases such as ischemic stroke.

Transcriptional regulation via TGF- $\beta$ signaling has been extensively studied. Activation of several genes has been linked to direct binding of Smad proteins to a conserved sequence (i.e., SBE composed of the sequence CAGAC), which occurs every 1024 base pairs in the genome (Massague and Wotton, 2000). For example, it has been demonstrated that bacterial-expressed Smad proteins bind directly to the SBE in the promoter of the Jun B gene, an early response gene that is potently activated by TGF- $\beta$, activin, and bone morphogenetic proteins (Jonk et al., 1998). Furthermore, activation of the enhancer in human Id1, a gene that encodes an inhibitor of DNA binding proteins, has been shown following binding of Smad proteins to the SBE, comprised of three repeats of CAGAC boxes (López-Rovira et al., 2002). Using ChIP followed by sequencing, a genome-wide map of Smad1/5 binding sites was generated in human umbilical vein endothelial cells (Morikawa et al., 2011). The authors identified that Smad1/5 preferentially bound to regions outside of the promoter of known bone morphogenetic protein-responsive genes with specific motif consisting of the canonical SBE flanked by GC-rich regions known as GC-SBE (Morikawa et al., 2011). We, therefore, hypothesized that in vivo BMP-9 treatment will induce phosphorylation of Smad1/5/8, which can then complex with Smad 4 and accumulate in the nucleus of rat brain microvascular endothelial cells. These data were well correlated with our western blot findings that showed an increase in Oatp1a4 protein expression 4 hours post-treatment with BMP-9. Furthermore, our ChIP data showed that the active Smad complex comprised of phosphorylated Smad1/5/8 and Smad 4 can directly bind to a Smad1/5/8 binding site in the Slcola4 gene. This is the first evidence in the scientific literature that TGF- $\beta$ /ALK1 signaling can directly regulate the Slco1a4 gene, which encodes an endogenous BBB transporter that can be targeted for CNS drug delivery.

Our data suggest that activation of ALK1 via treatment with exogenous BMP-9 activates the canonical ALK1/BMP-9 pathway. We have shown that receptor substrates for ALK1 (i.e., Smad1/5/8) are phosphorylated following administration of BMP-9, a biologic process that leads to nuclear translocation upon formation of a protein complex with Smad4. Nonetheless, crosstalk with other signaling pathways must be considered. In fact, bone morphogenetic proteins have been shown to induce gene transcription via effector molecules independent of Smad proteins (Sieber et al., 2009). For example, BMP-9 has been reported to activate the $\mathrm{JNK} /$ mitogen-activated protein kinase pathway (Yamaguchi et al., 1999). Furthermore, bone morphogenetic protein-dependent activation of extracellular signal-regulated kinase has been shown to induce kinase translocation into the nucleus and to activate target genes such as osteopontin or collagen I (Lai and Cheng, 2002). In our study, we have observed that BMP-9 treatment does not activate extracellular signal-regulated kinase 1/2 signaling or JNK signaling, data that emphasize the specificity of our BMP-9 treatment on TGF- $\beta$ /ALK1 signaling in rat brain microvessels. Ultimately, characterization of the precise regulatory mechanism involved in controlling functional

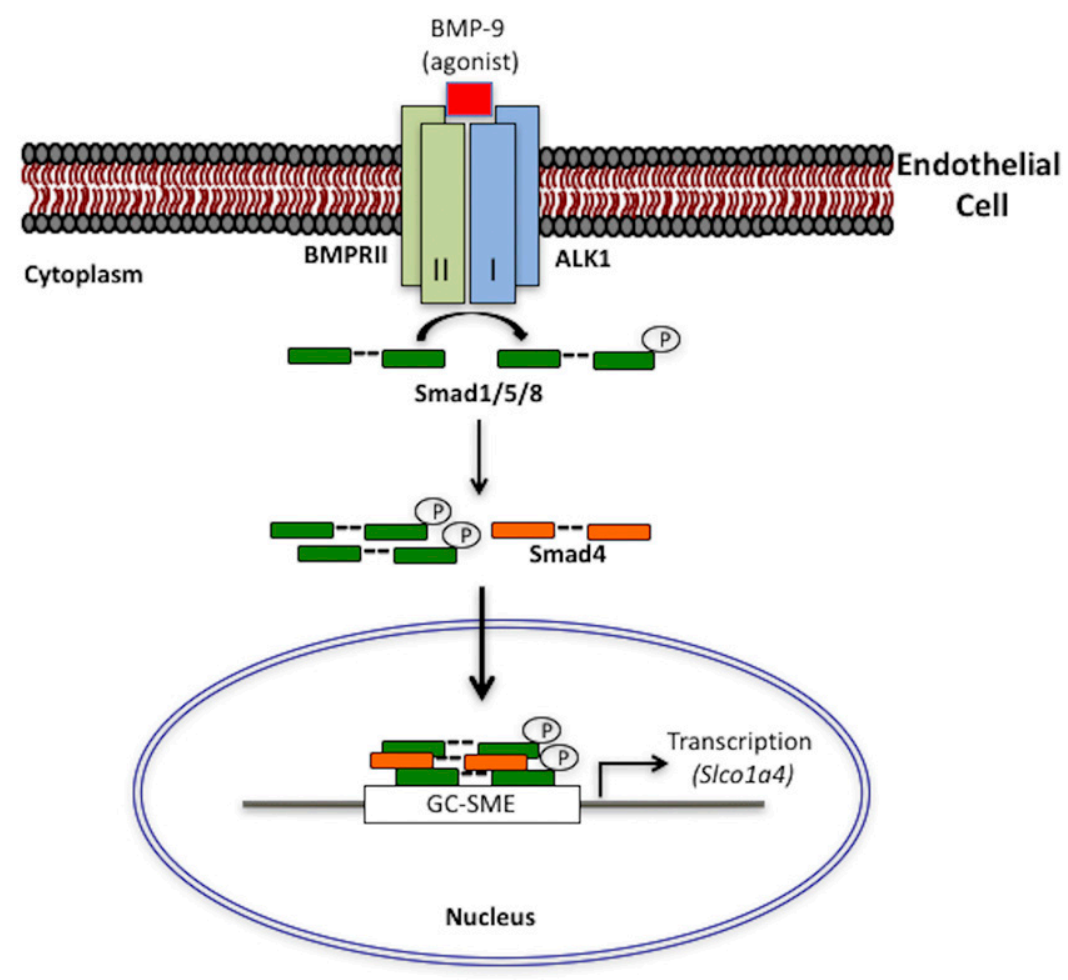

Fig. 10. TGF- $\beta / A L K 1$ signaling at the $B B B$ and regulation of the Slco1a4 gene. Based on data presented in this study, we propose that the ALK1 receptor is activated by BMP-9, which proceeds to phosphorylate substrate signal transducing proteins in the cytoplasm (i.e., Smad1/5/8). Activated Smad1/5/8 forms a heterotrimeric complex consisting of two pSmad1/5/8 and the common Smad (i.e., Smad4) and then translocates into the nucleus where it binds the SBE in the Slco1a4 gene promoter to induce transcription. This represents a novel mechanism that can be targeted pharmacologically to control CNS drug delivery at the BBB. Furthermore, this pathway can inform future studies aimed at developing novel strategies for treatment of neurologic diseases such as ischemic stroke. 
expression of Oatp1a4 at the BBB, as we have now shown for the first time, will inform development of novel drug delivery strategies for neurologic diseases.

Overall, this study describes increased functional expression of Oatp1a4 following dosing with the selective ALK1 agonist BMP-9. These data also demonstrate, for the first time, direct activation of the Slco1a4 gene via the TGF- $\beta$ /ALK1 signaling pathway (Fig. 10). These observations are critical because they imply that the ALK1 receptor is a molecular target that can control Oatp1a4 functional expression, and subsequently brain delivery of neuroprotective drugs. Overall, these results provide evidence that Oatp1a4 can be developed as a transporter target that can be exploited to facilitate CNS drug delivery.

\section{Acknowledgments}

We gratefully acknowledge Dr. Thomas P. Davis (Department of Pharmacology, University of Arizona College of Medicine) for helpful advice on this manuscript.

\section{Authorship Contributions}

Participated in research design: Abdullahi, Brzica, Ronaldson. Conducted experiments: Abdullahi, Brzica, Hirsch, Reilly, Ronaldson. Performed data analysis: Abdullahi, Ronaldson.

Wrote or contributed to the writing of the manuscript: Abdullahi, Ronaldson

\section{References}

Abdullahi W, Brzica H, Ibbotson K, Davis TP, and Ronaldson PT (2017a) Bone morphogenetic protein-9 increases the functional expression of organic anion transporting polypeptide 1a4 at the blood-brain barrier via the activin receptor-like kinase-1 receptor. J Cereb Blood Flow Metab 37:2340-2345.

Abdullahi W, Davis TP, and Ronaldson PT (2017b) Functional expression of P-glycoprotein and organic anion transporting polypeptides at the blood-brain barrier: understanding transport mechanisms for improved CNS drug delivery? AAPS J 19:931-939.

Arai K, Lok J, Guo S, Hayakawa K, Xing C, and Lo EH (2011) Cellular mechanisms of neurovascular damage and repair after stroke. J Child Neurol 26:1193-1198.

Barone E, Mancuso C, Di Domenico F, Sultana R, Murphy MP, Head E, and Butterfield DA (2012) Biliverdin reductase-A: a novel drug target for atorvastatin in a dog pre-clinical model of Alzheimer disease. $J$ Neurochem 120 $135-146$

Bronger H, König J, Kopplow K, Steiner HH, Ahmadi R, Herold-Mende C, Keppler D, and Nies AT (2005) ABCC drug efflux pumps and organic anion uptake transporters in human gliomas and the blood-tumor barrier. Cancer Res 65 $11419-11428$.

Brown MA, Zhao Q, Baker KA, Naik C, Chen C, Pukac L, Singh M, Tsareva T, Parice Y, Mahoney A, et al. (2005) Crystal structure of BMP-9 and functional interactions with pro-region and receptors. J Biol Chem 280:25111-25118.

Brzica H, Abdullahi W, Ibbotson K, and Ronaldson PT (2017) Role of transporters in central nervous system drug delivery and blood-brain barrier protection: relevance to treatment of stroke. $J$ Cent Nerv Syst Dis 9:1179573517693802

Brzica H, Abdullahi W, Reilly BG, and Ronaldson PT (2018a) A simple and reproducible method to prepare membrane samples from freshly isolated rat brain microvessels. J Vis Exp 135:e57698.

Brzica H, Abdullahi W, Reilly BG, and Ronaldson PT (2018b) Sex-specific differences in organic anion transporting polypeptide 1a4 (Oatp1a4) functional expression at the blood-brain barrier in Sprague-Dawley rats. Fluids Barriers CNS 15:25.

Brzica H, Breljak D, Krick W, Lovrić M, Burckhardt G, Burckhardt BC, and Sabolić I (2009) The liver and kidney expression of sulfate anion transporter sat-1 in rats exhibits male-dominant gender differences. Pflugers Arch 457:1381-1392.

Carone D, Librizzi L, Cattalini A, Sala G, Conti E, Cuccione E, Versace A, Cai R, Monza L, de Curtis M, et al. (2015) Pravastatin acute neuroprotective effects depend on blood brain barrier integrity in experimental cerebral ischemia. Brain Res 1615:31-41.

Curado F, Spuul P, Egaña I, Rottiers P, Daubon T, Veillat V, Duhamel P, Leclercq A, Gontier E, and Génot E (2014) ALK5 and ALK1 play antagonistic roles in transforming growth factor $\beta$-induced podosome formation in aortic endothelial cells Mol Cell Biol 34:4389-4403.

David L, Mallet C, Keramidas M, Lamandé N, Gasc JM, Dupuis-Girod S, Plauchu H, Feige JJ, and Bailly S (2008) Bone morphogenetic protein-9 is a circulating vascular quiescence factor. Circ Res 102:914-922.

Hagenbuch B and Meier PJ (2004) Organic anion transporting polypeptides of the OATP/SLC21 family: phylogenetic classification as OATP/ SLCO superfamily, new nomenclature and molecular/functional properties. Pflugers Arch 447:653-665.

Herrera B, Dooley S, and Breitkopf-Heinlein K (2014) Potential roles of bone morphogenetic protein (BMP)-9 in human liver diseases. Int J Mol Sci 15:5199-5220

Higgins JW, Bao JQ, Ke AB, Manro JR, Fallon JK, Smith PC, and Zamek-Gliszczynski MJ (2014) Utility of Oatp1a/1b-knockout and OATP1B1/3-humanized mice in the study of OATP-mediated pharmacokinetics and tissue distribution: case studies with pravastatin, atorvastatin, simvastatin, and carboxydichlorofluorescein. Drug Metab Dispos 42:182-192.

Hoque MT, Robillard KR, and Bendayan R (2012) Regulation of breast cancer resistant protein by peroxisome proliferator-activated receptor $\alpha$ in human brain microvessel endothelial cells. Mol Pharmacol 81:598-609.

Ibbotson K, Yell J, and Ronaldson PT (2017) Nrf2 signaling increases expression of ATP-binding cassette subfamily $\mathrm{C}$ mRNA transcripts at the blood-brain barrier following hypoxia-reoxygenation stress. Fluids Barriers CNS 14:6.

Jonk LJ, Itoh S, Heldin CH, ten Dijke P, and Kruijer W (1998) Identification and functional characterization of a Smad binding element (SBE) in the JunB promoter that acts as a transforming growth factor- $\beta$, activin, and bone morphogenetic protein-inducible enhancer. $J$ Biol Chem 273:21145-21152.

Lai CF and Cheng SL (2002) Signal transductions induced by bone morphogenetic protein-2 and transforming growth factor- $\beta$ in normal human osteoblastic cells. J Biol Chem 277:15514-15522.

Lebrin F, Deckers M, Bertolino P, and Ten Dijke P (2005) TGF- $\beta$ receptor function in the endothelium. Cardiovasc Res 65:599-608.

Lee W, Glaeser H, Smith LH, Roberts RL, Moeckel GW, Gervasini G, Leake BF, and Kim RB (2005) Polymorphisms in human organic anion-transporting polypeptide 1A2 (OATP1A2): implications for altered drug disposition and central nervous system drug entry. J Biol Chem 280:9610-9617.

Li W, Salmon RM, Jiang H, and Morrell NW (2016) Regulation of the ALK1 ligands, BMP9 and BMP10. Biochem Soc Trans 44:1135-1141.

Liu S, Levine SR, and Winn HR (2010) Targeting ischemic penumbra: part I - from pathophysiology to therapeutic strategy. J Exp Stroke Transl Med 3:47-55.

López-Rovira T, Chalaux E, Massagué J, Rosa JL, and Ventura F (2002) Direct binding of Smad1 and Smad4 to two distinct motifs mediates bone morphogenetic protein-specific transcriptional activation of Id1 gene. J Biol Chem 277:3176-3185

Löscher W and Potschka H (2002) Role of multidrug transporters in pharmacoresistance to antiepileptic drugs. J Pharmacol Exp Ther 301:7-14.

Massagué $J$ and Wotton D (2000) Transcriptional control by the TGF- $\beta /$ Smad signaling system. EMBO J 19:1745-1754.

Mayeur C, Kolodziej SA, Wang A, Xu X, Lee A, Yu PB, Shen J, Bloch KD, and Bloch DB (2015) Oral administration of a bone morphogenetic protein type I receptor inhibitor prevents the development of anemia of inflammation. Haematologica 100: e68-e71.

Miller AF, Harvey SA, Thies RS, and Olson MS (2000) Bone morphogenetic protein-9. An autocrine/paracrine cytokine in the liver. J Biol Chem 275:17937-17945.

Miller DS and Cannon RE (2014) Signaling pathways that regulate basal ABC transporter activity at the blood-brain barrier. Curr Pharm Des 20:1463-1471.

Montecucco F, Quercioli A, Mirabelli-Badenier M, Viviani GL, and Mach F (2012) Statins in the treatment of acute ischemic stroke. Curr Pharm Biotechnol 13:68-76. Morikawa M, Koinuma D, Miyazono K, and Heldin CH (2013) Genome-wide mechanisms of Smad binding. Oncogene 32:1609-1615.

Morikawa M, Koinuma D, Tsutsumi S, Vasilaki E, Kanki Y, Heldin CH, Aburatani $\mathrm{H}$, and Miyazono K (2011) ChIP-seq reveals cell type-specific binding patterns of BMP-specific Smads and a novel binding motif. Nucleic Acids Res 39:8712-8727.

Ni Chroinin D, Asplund K, Asberg S, Callaly E, Cuadrado-Godia E, Diez-Tejador E, Di Napoli M, Engelter ST, Furie KL, Giannopoulos S, et al. (2013) Statin therapy and outcome after ischemic stroke: systematic review and meta-analysis of observational studies and randomized trials. Stroke 44:448-456.

Noé B, Hagenbuch B, Stieger B, and Meier PJ (1997) Isolation of a multispecific organic anion and cardiac glycoside transporter from rat brain. Proc Natl Acad Sci USA 94:10346-10350.

Nour M, Scalzo F, and Liebeskind DS (2013) Ischemia-reperfusion injury in stroke. Intervent Neurol 1:185-199.

Oh SP, Seki T, Goss KA, Imamura T, Yi Y, Donahoe PK, Li L, Miyazono K, ten Dijke $\mathrm{P}$, Kim S, et al. (2000) Activin receptor-like kinase 1 modulates transforming growth factor- $\beta 1$ signaling in the regulation of angiogenesis. Proc Natl Acad Sci USA 97:2626-2631.

Ose A, Kusuhara H, Endo C, Tohyama K, Miyajima M, Kitamura S, and Sugiyama Y (2010) Functional characterization of mouse organic anion transporting peptide 1a4 in the uptake and efflux of drugs across the blood-brain barrier. Drug Metab Dispos 38:168-176.

Palmeira A, Sousa E, Vasconcelos MH, and Pinto MM (2012) Three decades of P-gp inhibitors: skimming through several generations and scaffolds. Curr Med Chem 19:1946-2025.

Pan J, Konstas AA, Bateman B, Ortolano GA, and Pile-Spellman J (2007) Reperfusion injury following cerebral ischemia: pathophysiology, MR imaging, and potential therapies. Neuroradiology 49:93-102.

Pardridge WM (2012) Drug transport across the blood-brain barrier. J Cereb Blood Flow Metab 32:1959-1972.

Potschka H (2010) Modulating P-glycoprotein regulation: future perspectives for pharmacoresistant epilepsies? Epilepsia 51:1333-1347.

Puente E, Saint-Laurent N, Torrisani J, Furet C, Schally AV, Vaysse N, Buscail L, and Susini C (2001) Transcriptional activation of mouse sst2 somatostatin receptor promoter by transforming growth factor- $\beta$. Involvement of Smad4. J Biol Chem 276:13461-13468.

Qosa H, Mohamed LA, Alqahtani S, Abuasal BS, Hill RA, and Kaddoumi A (2016) Transporters as drug targets in neurological diseases. Clin Pharmacol Ther 100:441-453.

Ronaldson PT and Davis TP (2013) Targeted drug delivery to treat pain and cerebral hypoxia. Pharmacol Rev 65:291-314.

Ronaldson PT, Demarco KM, Sanchez-Covarrubias L, Solinsky CM, and Davis TP (2009) Transforming growth factor- $\beta$ signaling alters substrate permeability and tight junction protein expression at the blood-brain barrier during inflammatory pain. J Cereb Blood Flow Metab 29:1084-1098.

Ronaldson PT, Finch JD, Demarco KM, Quigley CE, and Davis TP (2011) Inflammatory pain signals an increase in functional expression of organic anion transporting polypeptide $1 \mathrm{a} 4$ at the blood-brain barrier. J Pharmacol Exp Ther 336:827-839. 
Sieber C, Kopf J, Hiepen C, and Knaus P (2009) Recent advances in BMP receptor signaling. Cytokine Growth Factor Rev 20:343-355.

Sutherland BA, Minnerup J, Balami JS, Arba F, Buchan AM, and Kleinschnitz C (2012) Neuroprotection for ischaemic stroke: translation from the bench to the bedside. Int J Stroke 7:407-418.

Suzuki Y, Ohga N, Morishita Y, Hida K, Miyazono K, and Watabe T (2010) BMP-9 induces proliferation of multiple types of endothelial cells in vitro and in vivo. J Cell Sci 123:1684-1692.

Takasato Y, Rapoport SI, and Smith QR (1984) An in situ brain perfusion technique to study cerebrovascular transport in the rat. Am J Physiol 247:H484-H493.

Thompson BJ, Sanchez-Covarrubias L, Slosky LM, Zhang Y, Laracuente ML, and Ronaldson PT (2014) Hypoxia/reoxygenation stress signals an increase in organic anion transporting polypeptide 1a4 (Oatp1a4) at the blood-brain barrier: relevance to CNS drug delivery. J Cereb Blood Flow Metab 34:699-707.

Wang RN, Green J, Wang Z, Deng Y, Qiao M, Peabody M, Zhang Q, Ye J, Yan Z Denduluri S, et al. (2014) Bone morphogenetic protein (BMP) signaling in development and human diseases. Genes Dis 1:87-105.

Wei Z, Salmon RM, Upton PD, Morrell NW, and Li W (2014) Regulation of bone morphogenetic protein 9 (BMP9) by redox-dependent proteolysis. J Biol Chem 289 $31150-31159$.
Westholm DE, Salo DR, Viken KJ, Rumbley JN, and Anderson GW (2009a) The blood-brain barrier thyroxine transporter organic anion-transporting polypeptide 1c1 displays atypical transport kinetics. Endocrinology 150:5153-5162.

Westholm DE, Stenehjem DD, Rumbley JN, Drewes LR, and Anderson GW (2009b) Competitive inhibition of organic anion transporting polypeptide 1c1-mediated thyroxine transport by the fenamate class of nonsteroidal antiinflammatory drugs. Endocrinology 150:1025-1032.

Xu SY and Pan SY (2013) The failure of animal models of neuroprotection in acute ischemic stroke to translate to clinical efficacy. Med Sci Monit Basic Res 19:37-45. Yamaguchi K, Nagai S, Ninomiya-Tsuji J, Nishita M, Tamai K, Irie K, Ueno N Nishida E, Shibuya H, and Matsumoto K (1999) XIAP, a cellular member of the inhibitor of apoptosis protein family, links the receptors to TAB1-TAK1 in the BMP signaling pathway. EMBO J 18:179-187.

Address correspondence to: Dr. Patrick T. Ronaldson, Department of Pharmacology, College of Medicine, University of Arizona, 1501 N. Campbell Avenue, P.O. Box 245050, Tucson, AZ 85724-5050. E-mail: pronald@email. arizona.edu 